Pauli RaHKONEN (Helsinki)

\title{
Kargopolin ja Kenozeron alueiden etnohistoria
}

\begin{abstract}
The region of Kargopol and Kenozero is located in the middle zone of Baltic and Volgaic cultural influences that began in the Neolithic Period. The Volgaic influence on the onomasticon is obvious in the area of Kargopol. By contrast, it is almost invisible in the Kenozero region, where Finnic influence is remarkable. Especially the names of the lakes very often have a Finnic background. There are also some toponyms originating from Saami languages. The traditions of the local population in the Kenozero area confirm the picture presented by the onomasticon. The Finnic language spoken in the Kargopol-Kenozero region seems to originate from different sources. The old Russian imperial governmental boundaries most probably were formed according to the ancient territories of the Finno-Ugric tribes. Accordingly, the old Government of Olonets follows the distribution of Finnic toponyms in modern Karelia and the SouthWest Arkhangelsk oblast.
\end{abstract}

\section{Johdanto}

Kimmokkeena tämän artikkelin kirjoittamiseen ovat olleet Kenozeron ja Kargopolin seuduille vuosina 2000-2002 tekemäni kenttäretket. Tutkimusalueella on Venäjällä suorastaan legendaarinen maine. Kargopolin kaupunki on Pohjois-Venäjän vanhin, ja Kenozeron kansallispuisto on kiehtovalla tavalla aivan uniikki, ikään kuin elävä museo.

Olen käsitellyt aihetta poikkitieteellisesti arkeologis-historiallisen aineiston, substraattisanaston, nimistön sekä kansan perinnetiedon näkökulmista. Niinpä artikkeli rakentuu siten, että johdannon jälkeen luvussa 2 esittelen yleisellä tasolla tutkimusalueen. Luvussa 3 kuvailen alueen arkeologista taustaa ja varhaisimmissa historiallisissa dokumenteissa esiintyviä mainintoja Kenozeron ja Kargopolin seudusta. Eräs tärkeä tutkimuksen näkökulma on Arkangelin venäjän lounaismurteen ja siinä esiintyvien substraattisanojen tutkimus, jota käsittelen luvussa 4 viitaten jo tehtyyn tutkimukseen ja joihinkin kenttätyössäni tehtyihin omiin poimintoihini. Artikkelin keskeisin osa on kuitenkin luku 5, jossa esittelen ja analysoin alueen nimistöä. Luvussa 6 koskettelen tutkimuskohteen kansan perinnetietoa alan kirjallisuuden ja omien kenttätutkimusteni pohjalta ja luvussa 7 suoritan yhteenvedon.

Tutkittavan alueen arkeologiasta on kirjoittanut eritoten Igor Manjuhin mm. väitöskirjassaan Этногенез саамов (2005) ja artikkelissaan Позднекаргопольская культура. Саамы [культовые памятники] (1996). Mуӧs sellaiset arkeologit kuin N. A. Makarov (2006), E. A. Rjabinin (1997) ja L. A. Golubeva (1973) ovat sivunneet kyseisen alueen menneisyyttä. L. P. Komjagina (1994) on laatinut Arkangelin alueen murrekartaston. Toki jo Vladimir Dal' (1880-82) esitteli sanakirjassaan paljon Arkangelin alueen murresanoja. Myöhemmin kattavan esityksen venäjän murresanoista on tarjonnut tähän mennessä 47-osainen Словарь русских народньх говоров (SRNG), jonka kokoaminen alkoi jo vuonna 1965 ja josta vielä muutama 
osa on ilmestymättä. Kenozeron nimistöä ovat keränneet arkangelilaiset tutkijat V. J. Derjagin, Z. S. Derjagina ja G. I. Manihin. He ovat julkaisseet työnsä tulokset kirjassa Топонимика Кенозера 1-2 (1987). Seudun nimistöä ovat sivunneet myös A. K. Matveev (2001, 2004) ja A. A. Makarova (2012), S. A. Myznikov (2003b) ja Irma Mullonen (2013); ks. lähdeluettelo. Kargopolin alueen jokien nimistä on olemassa hyvä luettelo, jonka on laatinut N. N. Proničeva kirjassaan Журавлиныий край (1996). Kansatieteen näkökulmasta on kirjoittanut esim. G. P. Gunn kirjassaan Каргопольский озерный край (1984). ${ }^{1}$

\section{Kargopolin ja Kenozeron alue}

Itse Kargopolin kaupunki on Pohjois-Venäjän vanhin. Se on perustettu jo vuonna 1146. Asutus on syntynyt Onegajoen niskalle viiden kilometrin päähän siitä, missä Lačajärvi vaihtuu Onegaksi. Onega on yli $400 \mathrm{~km}$ pitkä seudun vesistöllinen valtaväylä, joka laskee vetensä Jäämereen. Monien koskiensa tähden se on suuremmille aluksille purjehduskelvoton. Lačajärvi on noin $34 \mathrm{~km}$ pitkä, ja suurin leveys on noin $14 \mathrm{~km}$. Järven pinta-ala on noin $330 \mathrm{~km}^{2}$. Järvi on kokoonsa nähden tavattoman matala. Keskisyvyys on vain noin 1,5 m. Tämä yhdistettynä alaviin aukeisiin rantoihin on ilmeisesti syynä siihen, että Lačan ympäristö on Venäjällä ainutlaatuinen kurkien muuttoaikainen kokoontumispaikka. Seudulle voi syksyisin kerääntyä jopa yli 10000 kurkea (Proničeva 1996: 31). Kenozero sijaitsee Kargopolista linnuntietä noin 75 km luoteeseen (kartta 1). Toisin kuin Lača, se on sokkeloinen järvi, joka monine lahtineen, niemineen ja saarineen muistuttaa paljon Suomen ja Karjalan järviä. Se koostuu oikeastaan kolmesta järvestä, joiden nimet ovat Kenozero, Dolgoe ozero ja Svinoë ozero. Yhteinen pinta-ala on noin 67 km² (Višnevskaja \& Gorohov 1997: 379).

Kenozero laskee vetensä Kenajokea myöten Onegaan. Kenozeron vesistöalueen latvavesien kautta on kulkenut vesireitti, joka lyhyen maakannaksen ylittäen jatkuu Vodlan vesistöön ja Ääniselle Karjalan tasavallan puolelle (Rjabinin 1997: 114, kartta 31). Etelässä on vuorostaan kulkenut tärkeä vesireitti Ylä-Volgalta Valkeajärvelle ja sieltä edelleen lyhyen kannaksen yli Vožejärvelle, josta vedet laskevat Svid'joen kautta Lačaan ja edelleen Onegaan. Näillä etelästä pohjoiseen ja lännestä itään kulkevilla vesireiteillä on ollut alueen historian kannalta suuri merkitys (kartta 1).

1. Tässä artikkelissa on kirjallisuusviitteissä venäläisten kirjallisten lähteiden osalta noudatettu sikäläistä tapaa merkitä vain etunimen ja patronyymin alkukirjaimet ellei alkuperäisteoksessa ole toimittu toisin tai ellei kirjoittaja ole koko nimellään Suomessa hyvin tunnettu. Näin on toimittu, koska monien kirjoittajien etunimiä olisi liian hankala jäljittää. 
Kargopolin ja Kenozeron alueiden etnohistoria 309

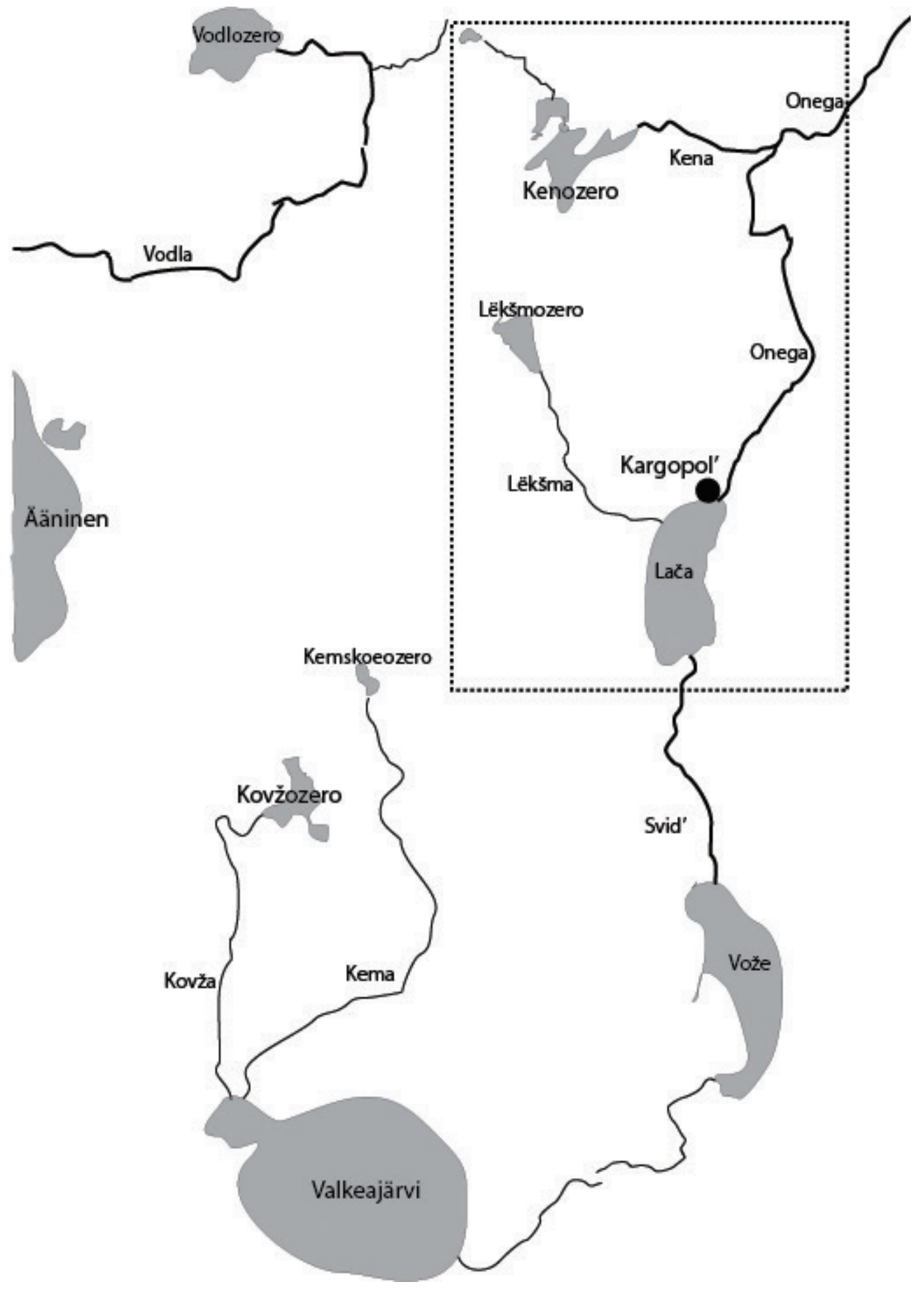

Kartta I. Onega-joen vesistöreitti ja Kargopolin-Kenozeron alue. 


\section{Katsaus arkeologiaan ja varhaisiin historiallisiin lähteisiin}

Kargopolin-Kenozeron alue on ikimuistoisista ajoista ollut Suomi-Karjalassa ja Ylä-Volgan alueilla vaikuttaneiden kulttuurien rajamaastoa. Varhaisella neoliittisella kaudella täällä kohtasivat Suomi-Karjalassa yleinen tyypillinen kampakeramiikka ja Volga-Okalla yleinen kuoppa(kampa)keramiikka eli Ljalovon keramiikka (Huurre 2001: 25, kartta V). ${ }^{2}$ Myöhäisellä neoliittisella aikakaudella alue jäi Suomi-Karjalassa yleisen Pöljä-Jysmän kulttuurin ja Volga-Okalla vallinneen Volosovon kulttuurin välimaastoon (Carpelan 1999: 263, kuva 4). Kargopolin alueella vallitsi tuolloin ns. Kargopolin kulttuuri (Gunn 1984: 20; Patrushev 2000: 49, Fig. 14), joka ilmeisesti oli kuoppa(kampa)keramiikan jatke. Pronssikaudella raja hämärtyi, koska Ylä-Volgalta levisi suhteellisen nopeasti ns. itäinen tekstiilikeramiikka Karjalaan, Sisä-Suomeen ja aina Pohjanmaalle asti (Carpelan 1999: 269). Määrätynlainen nimistö heijastaa väestöliikettä, joka sijoittuu melko tarkasti tekstiilikeraamisen alueen sisälle. Taustalla olevaa kieltä olen kutsunut länsiuralilaiseksi $x$-kieleksi (Rahkonen 2013a: 34-36). Tekstiilikeramiikan sisällä oli toki paikallisia variantteja, Suomessakin jopa useita (Lavento 2001: 167-168). Varhaisella rautakaudella Kargopolin-Kenozeron alue muuttui jälleen kulttuurilliseksi rajaseuduksi. Siellä muotoutui ns. myöhäiskargopolin kulttuuri, joka rajoittui karkeasti ottaen kolmen suuren järven, Lačan, Äänisen itärannan ja Valkeajärven sisään jäävälle alueelle (Manjuhin 2005: 21-22). Mullonen (2005: 30) kutsuukin aluetta "järvienväliseksi alueeksi”. Kyseinen keraaminen kulttuuri sai vaikutteita kolmelta taholta: 1) Ala-Kaman ja Keski-Volgan Ahmylovon-Anan'inon keramiikasta, 2) Volga-Okan tekstiilikeramiikasta ja 3) paikallisesta tekstiilikeramiikasta (Lavento 2001: 39-42 sekä siihen liittyvä kirjallisuus). Manjuhin (2005) yhdistää myöhäiskargopolin kulttuurin saamelaisen etnoksen syntyyn. Tästä keskustellaan myöhemmin nimistöanalyysin yhteydessä luvussa 7.4. Kargopolin seutu ja myöhäiskargopolin kulttuurin esiintymisalue jäivät Suomi-Karjalan Luukonsaaren ja kamalais-volgalaisten Ahmylovo-Anan'inon kulttuurin sekä Volga-Okan tekstiilikeraamisten kulttuurien (Djakovo ja Gorodišče) väliin.

Varhaiset kirjalliset lähteet kertovat, että slaavien invaasion seurauksena (n. 900-1200 jKr.) Lačajärvi kuului Rostov-Suzdalin (Ylä-Volga) ruhtinaskunnan piiriin, mutta itse Kargopol' sekä läheinen Kenozero Novgorodin piiriin (Rjabinin 1997: 114, kuva 31). Ennen slaavien saapumista (ehkä 800-luvulta alkaen) alkoi itämerensuomalaista väestöä (vepsäläisiä?) levittäytyä Laatokan kaakkoisrannoilta kohti itää. Arkeologisesti on puhuttu ns. vepsäläisistä kurgaanihautauksista, jotka ulottuivat lähelle Valkeajärveä (Rjabinin 1997: 90, kuva 25). Kiinnittäisin huomiota siihen, että Lača-järvellä ja Valkeajärven itäpuolella "vepsäläisten" kurgaanien asemesta on löydetty ns. maakuoppahautauksia (ven. грунтовые могильники). Муӧs nimistö osoittaa, etteivät itämerensuomalaiset hydronyymit ulotu ainakaan merkittävästi Valkeajärven kaakkoispuolelle (kartat 2 ja 3). Näyttäisi siis siltä, että myöhempi jako Novgorodin ja Rostovin maihin heijasti tätä varhaisempaa jakoa toisaalta itämerensuomalaisten/saamelaisten ja toisaalta merjalaisten heimojen välillä.

2. Tässä artikkelissa käytetty termi Suomi-Karjala koostuu nykyisestä Suomen, Karjalankannaksen ja Venäjään kuuluvan Karjalan tasavallan alueista. Termi Volga-Oka tarkoittaa Volgan yläjuoksua Nižnij-Novgorodista ylöspäin ja Okan alajuoksua Kalugan mutkasta alavirtaan sekä näiden väliin jäävää kannasta. 
Tässä yhteydessä haluaisin Mullosen (2003: 347) tavoin kyseenalaistaa sitä vanhaa näkemystä, jonka mukaan kronikoiden Veś-kansa tarkoitti vepsäläisiä. Ensiksi, alkujaan vain etelävepsäläiset ovat kutsuneet itseään vepsäläisiksi (Bubrih 1948: 30). Mielestäni Valkeajärven alueen tuntumaan saapuneet vepsäläiset omaksuivat Veśkansalta etnonyymin vepsä. Toiseksi, vaikka itämerensuomalainen (vepsäläinen?) nimistö ulottuukin Valkeajärven länsi- ja lounaisrannoille asti, on sen esiintymistiheys siellä jo harvahkoa. Missään tapauksessa Valkeajärven seutu ei siis ollut vepsäläisten ydinaluetta. Kronikoiden aikaiset hallinnolliset keskukset Krutik ja sittemmin Belozero sijaitsivat kumpikin itämerensuomalaisen nimistöalueen ulkopuolella tai aivan reunalla (ks. Mullonen 2005: 31, kartta). Oletettavaa on, että nimistön todistuksen perusteella etninen ryhmä nimeltä veś puhui kieltä, jonka sanastossa esiintyi sana *ßoj 'joki, puro' < kantaural. *woja sm oja (ks. Saarikivi 2004: 199-201). Tämä nimistö on keskittynyt pääasiallisesti Valkeajärven eteläpuolelle, mutta Šeksnan länsipuolelle. Joitain esiintymiä on myös Vože- ja Kubena-järvien tuntumassa (kartta 4). Lisäksi hajatapauksia on Syvärin vesistöaltaan alueella ja Kargopolin alueella. Tämä nimen perusosa liittyy aina jokiin ja puroihin. Useimmiten -buj/-boj-perusosaisten nimien määriteosat ovat sangen vaikeaselkoisia eivätkä missään tapauksessa itämerensuomalaista tai edes parasaamelaista alkuperää. ${ }^{3}$ Äänteellisessä mielessä kielen itämerensuomalaisuutta vastaan todistavat äänteet $\check{c}, \check{z}, \check{s}$ ja saamelaisuutta vastaan $h$. AVO = Atlas Vologodskaja oblast' 2008 tuntee seuraavanlaisia nimiä: Am $\mid$ buj (53G5), An $\mid$ buj (32B1), Ar|buj|ka (73B5), Buj|lahta (14G3), Bu|ozero < *Buj|ozero (54B2), $\check{C} u z ̌|b o j| k a$; Niž. (30G2), Hel|buj (51A5), Kače $\mid$ boj (54G1) Kiz|boj (54V2), Laj|buj (22B2), Než $\mid$ buj (72B1), Rodo $|m|$ boj (53B5), Rot $\mid v o j ~(14 B 2)$, Sjam $\mid$ buj (18B1), Uz $\mid$ boj $\mid k a$ (55B5), Voro $\mid$ buj (52B1), Šer|buj (60G2), Šuš|boj (53B5). Aiheesta keskustellaan jäljempänä enemmän.

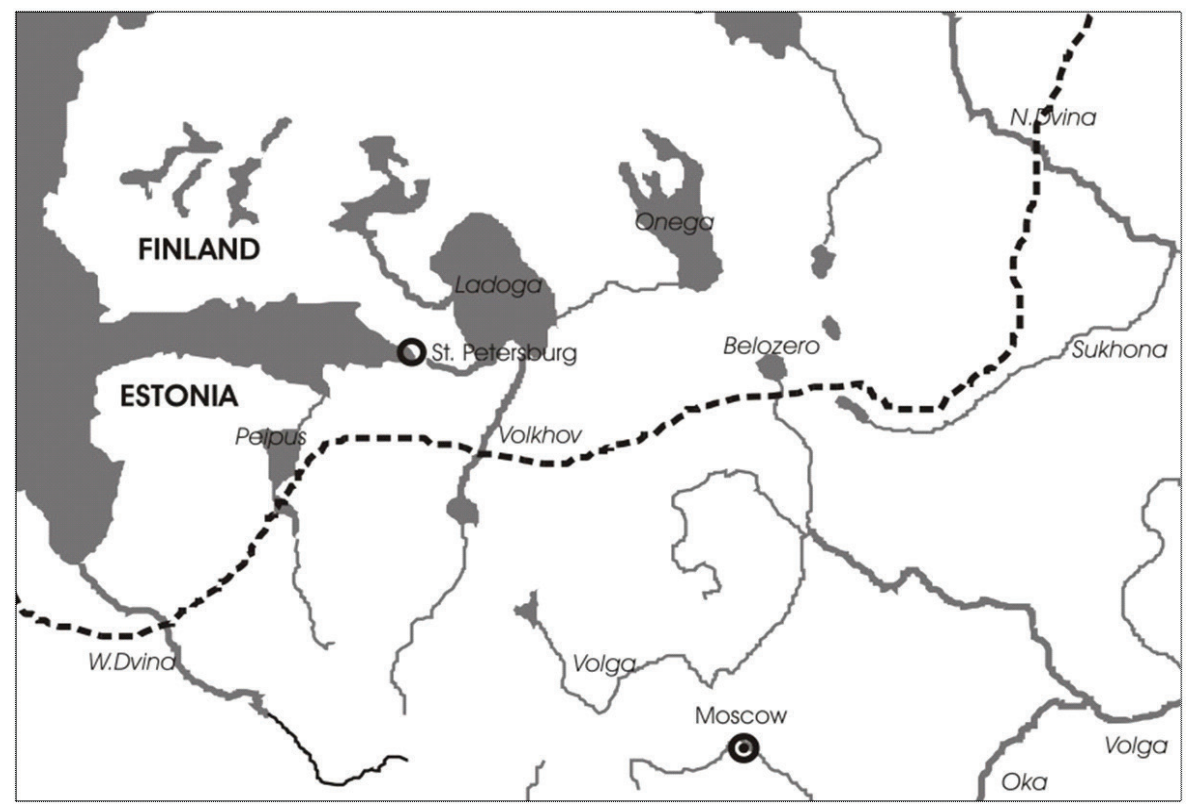

Kartta 2. Itämerensuomalaisen vesistönimistön raja kaavamaisesti esitettynä.

3. Termiä parasaame on käytetty Äänisen ja Valkeajärven välisellä kannaksella puhutusta kantasaamelle läheisestä kielestä (Aikio 2006: 42). 


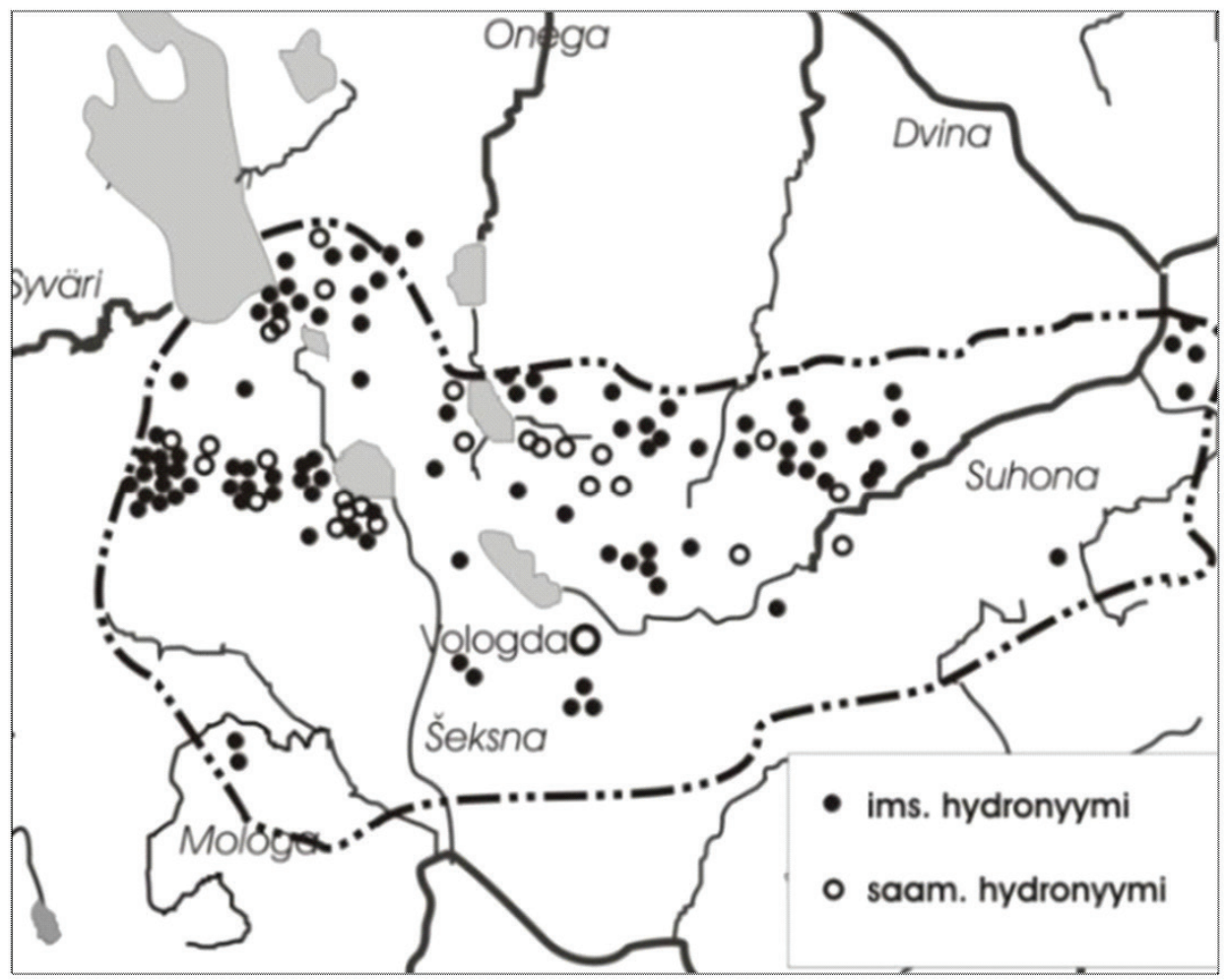

Kartta 3. Itämerensuomalaisia ja (para)saamelaisia hydronyymejä Vologdan alueella [oblastissa] (AVO).

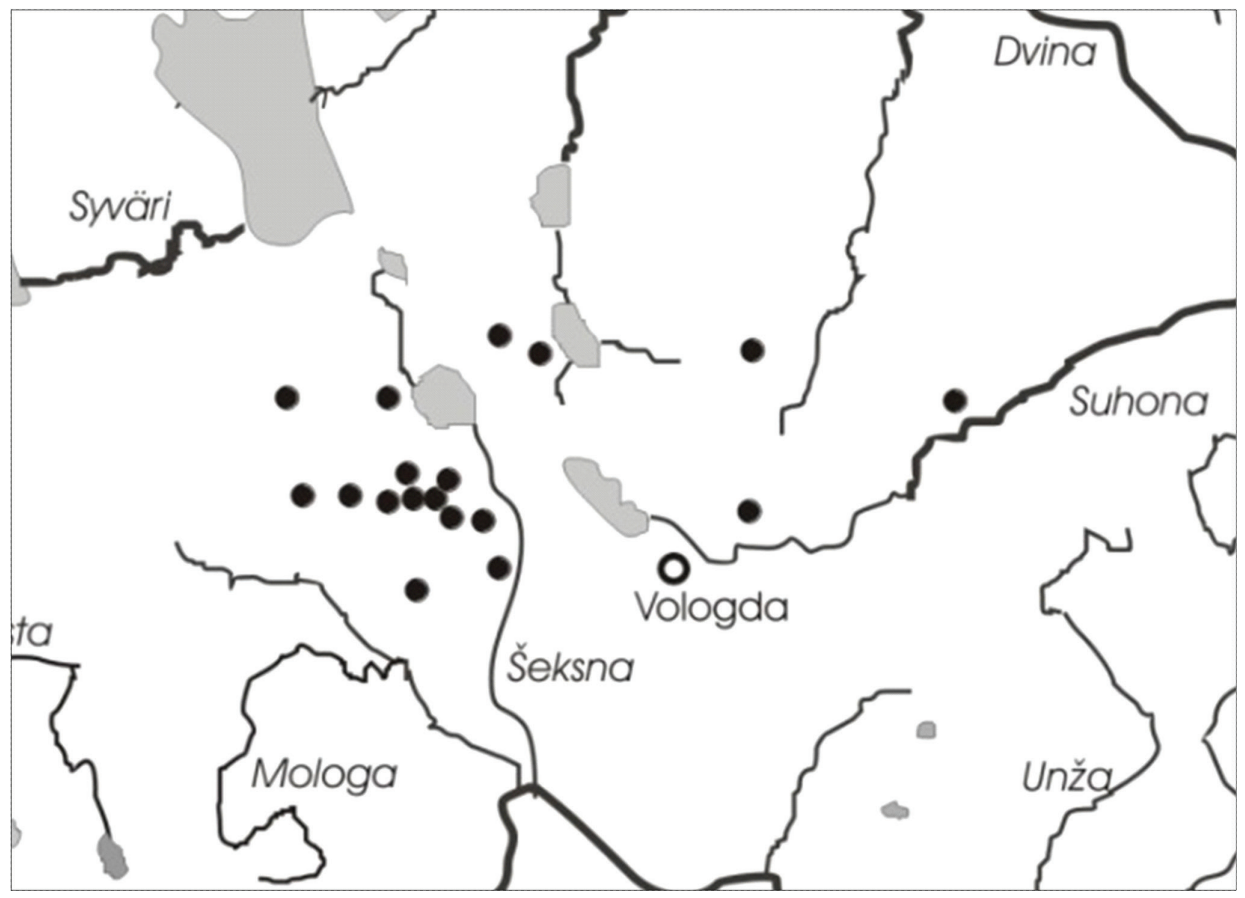

Kartta 4. Valkeajärven alueen -buj/-boj hydronyymit (AVO). 


\section{Kargopolin ja Kenozeron alueitten substraattisanasto}

On vanhastaan tunnettua, että itämerensuomalaista substraattisanastoa esiintyy tutkittavalla järvien välisellä alueella (mm. Dal' ${ }_{1-4}$ 1880-82; Kalima 1915; Komjagina 1994, SRNG ${ }_{1-47}$ 1965-2014). Itse keräsin sanoja Kenozeron alueella. Hyvinä informantteina toimivat etenkin muualta muuttaneet asukkaat, joiden korviin heille vieraat paikalliset sanat olivat erityisesti jääneet mieleen.

Paikallisten asukkaiden venäjän kielestä voi mainita muutamia erityispiirteitä. Ensinnäkin esiintyi tavujen etupainoisuutta silloinkin kun sitä ei standardivenäjässä ole. Esimerkiksi vanhukset sanoivat bólšoj dom 'suuri talo' vahvalla okanjella ja etupainolla, kun moskovalainen olisi sanonut balš́ój dom. Jotkut äänsivät jégo 'hänen (mask.)' eikä standardivenäjän mukaisesti jevó [ezo]. Samoin esiintyi kógo 'kenen' eikä kavó [кого]. Eräs keski-ikäinen rouva Šalákušan kylästä Plesetskistä etelään totesikin: "Me emme osaa kunnon venäjää emmekä tiedä, mihin sanan paino tulisi asettaa". Taipumus etupainoisuuteen on ilmeisesti itämerensuomalaista substraattivaikutusta (ks. Požarickaja 1997: 17-25; Saarikivi 2006a: 26). Myös paikallisen venäjän sanastossa esiintyi varsin erikoisia piirteitä. Seuraavassa esitän mahdollisten substraattisanojen luettelon, ensin koostuen itse havaitsemistani ja sitten Komjaginan (1994) keräämistä sanoista.

Substraattisanoja Kenozerolla (kenttätyö 2000-2002) (itämerensuomalaiset vastineet SSA I-3)

I. murá 'ruoka, jossa on aineksina murennettua leipää, vettä ja suolaa' smInk muru 'maidosta ja leivänmuruista tehty ruoka' | ka muru 'ruoka' | sm sanonta: murua (ruokaa) rinnan alle 'syödä' || Ilmeisesti < ve mypá 'kaljaan tai veteen sekoitettu leivän ja sipulin sekainen suurus' [esiintymisalue: Novgorod, Vologda, Olonec, Smolensk] (SRNG s. v. mypá). Toisaalta sanan pohjoinen levintä voisi viitata myös suomalais-ugrilaiseen substraattiin venäjän pohjoisissa murteissa.

\section{2. mórdi 'merta'}

sm ka merta | ly ve merd || Ilmeisesti monikon tunnus -i johtuu siitä, että käytettiin mertoja, joissa oli ikään kuin useampia mertoja peräkkäin. Myznikov (2003a: 170) esittää, että mórda on muunnos varhaisemmasta asusta mërda; [esiintymisalue: Olonec, Jaroslavl, Vologda, Belozero, Novgorod, Leningrad]; ks. myös SRNG s. v. мерда.

\section{3. káčka 'häkä'}

sm katku | ka katšku 'käry, katku, häkä' | ve katšk; ks. äännehistoriasta jäljempänä käytävä keskustelu. || Tätä sanaa eivät tunne Dal' eikä SRNG.

4. paráto 'hyvin, sangen'; Komjagina (1994) poráto

mdE paro 'hyvä' | mari poro 'hyvä' | sm parempi, paras < *para || Dal' (Dal' s. v. nopá) on katsonut sanan palautuvan venäjän sanaan nopá 'aika, josta mahdollisesti mm. sana nоринье 'terveys, voima' (ks. ESRJ s. v. nopumb mm. 'lihoa, suureta, auttaa'). Sanan nopámo [porato] pohjoinen levintä kuitenkin viittaa mielestäni suomalais-ugrilaiseen substraattiin; ks. SRNG:n mukainen levintä: Pskovsk, Novgorod, 
Vologda, Arkangel, Olonec, Murmansk, Komi, Perm, Siperia, Vladimir, Moskova, Tver. Oletan, että sana lainautui novgorodilaiseen venäjään paikallisten tšuudien kieleen kuuluneesta sanasta *para 'hyvä' eikä juonnu venäjän sanasta nopá 'aika'. Myönnän kuitenkin, että selitykseni on epävarma.

5. kur'já 'lahti, salmi (joen)'Vastaava sana esiintyy myös komin kielessä (komi kur' já 'lahti, salmi') sekä pohjoisvenäläisissä murteissa. SRNG s. v. курья esiintymisalue: Orenburg, Udmurtia, Perm, Ural, Kirov, Kostroma, Arkangel, Novgorod, Pečora, Komi, Olonec, Länsi-Siperia. Vasmer (ESRJ s. v. курья) esittelee keskustelua, joka koskee erilaisia lainautumissuuntia suomalais-ugrilaisten ja venäläisten mahdollisten originaalien välillä, mutta ei ota asiaan suoranaisesti kantaa. Hänen mukaansa sana esiintyi jo vanhassa Novgorodin venäjässä, mutta hän ei esitä mitään kantaslaavilaista originaalia. Katson sanan palautuvan suomalais-ugrilaiseen, mutta ei komilaiseen originaaliin. Perustelen näkemystäni sanan pohjoisella levinnällä ja sillä, ettei sanalla ole hyvää kantaslaavilaista etymologiaa. Alkujaan sana voi olla lainattu jostain paleo-eurooppalaisesta kielestä. Suffiksaalinen -ja voisi olla novgorodin venäjästä peräisin. Keski-Venäjällä Okan alueella esiintyy ilmeisestikin meščëralainen sana $k u r(V)$ 'järvi' (Ahlqvist 2000: 27; Rahkonen 2012: 30), mikä myös voi liittyä tähän yhteyteen. Äänteellisessä mielessä meščëralainen $k u r(V)$ voi palautua samaan originaaliin kuin vepsän $\operatorname{kar}(a)$ 'lahti' (Zajceva - Mullonen 1972 s. v. kar[a]).

\section{6. luhta 'luhta'}

sm 'rantaniitty, joka keväisin jää tulvan alle' | ka 'keväisin tulviva niitty, ruohoa kasvava rantavesi, (tulva)lampi' | ly luht(e) 'lätäkkö, luhtaniitty' | ve luht 'lätäkkö, matalikko, luhtaniitty' || SRNG (s. v. лухma) antaa sanalle mm. seuraavat merkitykset 'lahti; lahden soistunut, sammaloitunut ranta; seisova virtaamaton vesi' [esiintymisalue: Olonec, Arkangel/Kargopol', Vologda, Belozero]; ks. myös Myznikov 2003b s. v. luhta.

\section{7. lahta 'lahti'}

sm lahti | livvi lahti | ly ve laht (pääosin keskivepsässä) 'lahti' || SRNG s. v. лаxma esiintymisalue: Arkangel, Olonec, Leningrad, Pohjois-Venäjä, Komi.

\section{8. mjánda 'mänty'}

sm ka mänty 'petäjä' | ly mänd(ü) id. | ve mänd id. || SRGN s. v. мянда esiintymisalue: Vologda, Arkangel, Olonec, Pečora, Komi.

Myös joitain venäjän kannalta erikoisia sanontoja löytyi:

I) черепуга не рамандад 'pää ei toimi'

- Poikkeava verbimuoto, standardivenäjässä pitäisi olla рамандает.

- Itse verbiä ei esim. Dal' eikä SRNG tunne, mutta se lienee johdettu adjektiivista рамяный 'voimakas', josta adverbi рамяно 'oikein, erittäin, hyvin' (ESRJ s. v. рамяный).

2) Verbi рахмановать 'tuhlata rahaa', jota ei Dal' eikä SRNG myöskään tuntenut; vrt. adjektiivi рахманный mm. 'laiska, heiveröinen, kömpelö' (ESRJ s.v. рахманный). 
Kargopolin-Kenozeron alueella esiintyviä substraattisanoja poimittuna L.P. Komjaginan (1994) murreatlaksesta (itämerensuomalaiset vastineet SSA I-3)

n:o 3 lúda 'savinen maaperä, liete, särkkä, kivikkoinen pohja, kivinen ranta, kivikkoinen maa' || vrt. Dal' 1881 s. v.

лу́да; Kalima 1915: 155; SRNG s. v. луда.

- sm luoto 'pieni kallioinen saari, kivinen tai kallioinen paikka pellossa' | ka luoto 'luoto, kari; muta- tai hiekkapohjainen matalikko' | ly luod(o) 'luoto' | ve lodo 'matalikko'

n:o 17 jánga 'kosteikko, suo' || Myznikov (2003b: 310 ja siihen liittyvä kirjallisuus) mainitsee, että Kargopolin piirissä esiintyy sana janga 'suo, vesaikkoinen metsä', Pleseckin, Belomorskin sekä Onegan piirissä 'upottava suo', Kargopolin ja Pleseckin piireissä myös 'kuiva suo, aava sammalsuo'.

- sm jänkä 'suo, räme' < ksa *jē esiintyneen myös merjan kielessä, ?*jängä tai *jängə; ks. vesistönimet Jango|ra (AJO 17A4), Janga (AKO 112A3), Janguža (GBO 256).

n:o 2I tájbola 'tiheä synkkä metsä, metsätie kylien välillä, lettosuo, heinäntekopaikka' || vrt. Dal' 1882 s. v. mай; Kalima 1915: 223; SRNG s. v. тайбола levintä: Arkangel, Novgorod, Vologda, Komi, Murmansk, Nenec, Siperia.

- sm taival, taipale 'kuljettava väli, (pitkä) matka asumattomilla seuduilla, vesien välinen kannas' | ka taival 'matka, kyläväli, vesien välinen kannas' | ly taibal(eh) 'taival, kahden kylän väli'

n:o 23 sógra, šógra 'soistunut metsä, metsäsaareke, pensaikko' || vrt. Dal' 1882 s. v. córpa, s. v. móxpa; SRNG s. v. corpa.

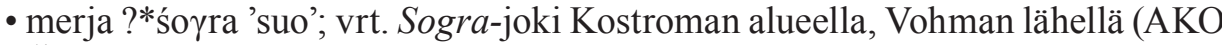
45A3) Šohra (AKO 156B3) Unžan alajuoksulla ? > ve Pondala sohring 'soistunut alue' (Zajceva-Mullonen 1972: 517)

n:o 26 káren'ga 'vitsa, keppi, oksa' | koren'gá 'ohuita puita kasvava metsä' || vrt. Dal' 1881 s. v. ка́ренга; Kalima 1915: 106; SRNG s. v. каренга, кареньга, кореньга esiintymisalue: Arkangel, Perm, Sverdlovsk, Ural, Siperia.

- sm karanko, karanka 'pystyyn kuivunut nuori puu, kuivunut oksa, riuku, seiväs' | ka karankokuusi 'pitkä ja hoikka, kuivahtanut kuusi' | ly kūzen karangahaine 'kuivunut kuusi'

n:o 27 hónga 'pystyyn kuivunut puu' || vrt. Dal' 1882 s. v. хонга; Kalima 1915: 238 .

- sm honka 'kookas, vanha mänty' | ka honka 'vanha, suuri mänty' | ly hoyg(e) 'honka (hirreksi kelpaava)' | ve hoyg 'mänty'

n:o 29 míglá 'lehtikuusi < *niglá (vanhassa venäjässä *n $>m$ oli yleinen; esim. *norrman > murman); SRNG s.v. мигла, негла, нёгла esiintymisalue: Arkangel/ Kargopol', Olonec, Vologda, Vladimir, Novgorod, Venäjän Pohjola. 
- ven Vologda negla 'havupuu' (Dal' II 1881 s. v. негла) | ka niekla 'havupuun neulanen' | ve ńeglāne 'neulanen'

n:o 30 pák(k)ula 'koivun kääpä' || vrt. Kalima 1915: 178-179; SRNG s. v. пакула esiintymisalue: Arkangel, Vologda, Komi, Olonec, Murmansk.

- sm pakkula 'kääpä, taula' | ka pakkuli 'taulakääpä' | ly pakkul' 'koivunpahka' | ve pakkal pakl 'taula, kääpä'

n:o 3 I kárzát' 'hakata, katkaista lyhyemmäksi' || vrt. Dal' 1881 s. v. ка́pзаmb; Kalima 1915: 108; SRNG s. v. карзать esiintymisalue: Novgorod, Arkangel, Olonec, Leningrad, Vologda, Komi.

- sm karsia 'hakata puista oksia' | ka karsie 'hakata oksia, karsia' | ly karžida id. | ve kaŕśta id.

n:o 48 sárgá, sáŕga tuohi- tai puusuikale korin punomiseen, kalastusväline ${ }^{4}$, metallipala, joka kiinnittää viikatteen terän puiseen varteensa, päreristikko sienien kuivaukseen' || vrt. Dal' 1882 s. v. cápza; Kalima 1915: 213; Myznikov 2003a: 156; SRNG s. v. capza.

- sm sarka 'peltokaistale, metsäpalsta'; smSavo 'tuohinauha' | ka sarka 'tuohisuikale, peltosarka, kangas' | ly sarg 'kaistale, suikale, nauha' | ve sarg '(tuohi-, niini)suikale, peltosarka'

n:o 5I šálga' 'puunkaadonalainen osa metsää, huono metsä, matalakasvuinen metsä, huonoa puuta kasvava metsä, tiheä synkkä metsä' || vrt. Dal' 1882 s. v. ша́лгa; Kalima 1915: 244.

- sm salo 'laaja metsäseutu, erämaa' | ka ly salo 'salo, korpi'

n:o 5I šálga 'haravan osa, johon piit kiinnittyvät, äkeen eräs puinen osa' || vrt. Kalima 1915: 245.

- sm salko 'ohuehko, pitkä tanko, seiväs, riuku' | ka salko 'salko, seiväs, riuku, pieleksen pystypuu' | ly salgo 'salko heinäsuovassa' || ksa *ćōlkōj mm. 'jääverkon uittoseiväs' | mdM śalga mm. 'kalikka, keppi, sauva' $\sim$ ? merja *šalga tai śalga $>$ Šalga joki Jaroslavlin alueella, Danilovin lähellä (AJO 19A3)

n:o 74 šug, suh 'ohut jääriite' || vrt. Dal' 1882 s. v. uyzá; Kalima 1915: 248.

- ? sm sohjo; || ? merja *šuga 'sohjo'; vrt. Šugo|ma-joki Kostroman alueella, Čuhloman seudulla (AKO 30A1); Šug|ozero Leningradin alueella Paša-joen latvavesillä lähellä Tihvinää (ALO 59B4), mutta voi olla <*Šuig|ozero

n:o 84' kurževina, kurža 'kuura' || vrt. Dal' 1881 s. v. куржyxa'; Myznikov 2003a: 93; SRNG s. v. куржевина levintä: Arkangel, Komi, Vjatka, Kirov, Jaroslavl, Vologda, Kostroma, Siperia.

- sm kuura 'huurre'

n:o $84^{2}$ harmoha 'kuura' || vrt. Myznikov 2003a: 100, 93, kartta 21.

- sm härmä 'kuura, huurre' | ka härmä 'huurre, vähäinen lumi' | ly härm 'huurre' n:o 128 kibas 'verkon kives (paino)' || vrt. Dal' 1881 s. v. ки́басъ; Kalima 1915: 116; SRNG s. v. кибас levintä: Siperia, Vjatka, Arkangel, Vologda, Pečora, Kostroma, Belomorsk.

- sm. kives 'verkonpaino' | ka kives 'verkonpaino' (KKS s. v. kives) | ve kivez 'verkonpaino' [Ojatin latvoilla] (Zajceva - Mullonen 1972: 210)

4. Ilmeisesti liistekatiska. 
n:o I29 šuika 'sukkula verkonpunontaa varten' \|

- sm ka sukkula| ly sukkulaine | ve sukloine 'sukkula'

Sanan alkuperä on kuitenkin epävarma.

n:o I49 tujes 'tuohiastia (sylinterinmuotoinen)'

- sm tuohinen : tuohis- 'tuohesta tehty' | ka tuohi | ly tuoh(i) | ve tohi

Sanan on oletettu palautuvan permiläiseen originaaliin, vaikkakin venäjän murresanan melko läntinen ja eteläinenkin levintä herättää kysymyksiä. Sana voi olla lainautunut komiin jostain merjalaistyyppisestä kielestä, koska se esiintyy myös Keski-Venäjän murteissa (ks. ESRJ s. v. myec). SRNG s. v. myec levintä: Vologda, Olonec, Karjala, Arkangel, Komi, Murmansk, Jaroslavl, Kostroma, Novgorod, Rjazan', Meščëra, Tula, Vjatka, Perm, Kama, Ural, Siperia.

Tarkasteltaessa edellä esitettyjen Arkangelin venäjän lounaismurteessa (ks. kartta 6) esiintyvien substraatti- tai lainasanojen tarkempia taustoja, voidaan tehdä seuraavanlaisia huomioita: Semanttisesti voidaan - yllättävää kyllä - KargopolinKenozeron venäjän itämerensuomalaisiin substraattisanoihin parhaiten yhdistää suomen sanojen merkitys. Todennäköinen syy lienee kuitenkin "tekninen". Suomi on säilynyt hyvin arkaaisena kielenä. Sanasto on säilynyt pitkään suhteellisen muuttumattomana ja suomen murresanastoa epäilemättä on itämerensuomen itäiseen ryhmään verraten saatu paremmin kerättyä talteen. Lisäksi vanhan kirjasuomen sanasto on jo 1500-luvulta Agricolasta lähtien kohtalaisen laajasti tallennettuna. Nykyiset karjalan, lyydin ja vepsän kielet ovat voineet menettää huomattavan osan vanhoista sanoistaan, joita ei ole saatu kerättyä talteen. Sanojen vastaavuuksien puuttumisen osalta voidaan - jälleen melko yllättäen - todeta, että eniten vastaavia sanoja puuttuu vepsästä (7 tapausta). Seuraavana tulevat lyydi (4 tapausta), karjala (2 tapausta) ja suomesta ei puutu yhtäkään.

Äänteellisistä seikoista puhuttaessa voidaan havaita, että sanassa *imsKenozero kačka 'häkä' esiintyy äänteellinen vastaavuus - čk- sekä livvin katšku että vepsän katšk sanojen kanssa. Sitä ei esiinny muualla itämerensuomessa. Sinänsä kačka edustaa arkaaista äänteellistä muotoa sanassa säilyneen affrikaattansa $\check{c}$ tähden (vrt. mdE kačamo 'savu', $\mathrm{MWB}_{2}$ s. v. kačams). Suomessahan affrikaatta on yleensä $t$ :1listynyt niin kuin eteläviroa lukuunottamatta muissakin itämerensuomalaisissa kielissä on tapahtunut (mm. Kallio 2006: 233; Sammallahti 1999: 76). On vaikea sanoa, onko sana kulkeutunut vepsästä tai livvistä Kenozerolle vai onko se siellä omaperäinen. Niinpä sekin on mahdollista, jopa luultavaa, että vepsä on saanut sen varhaiselta itämerensuomen taipaleentakaiselta ryhmältä Kenozerolta, ja livvissä se on vepsäläiskontaktien perua. Terho Itkonenkin (1981) pohti tätä mahdollisen lainanantajana toimineen substraattikielen problematiikkaa artikkelissaan Zur Geschichte der ts-Verbindung in den westfinnischen Dialekten. Toinen mahdollinen arkaainen affrikaatta č esiintynee järven nimessä Lača livvi lattšu 'lattea, matala', ve lača $\mid k$ mm. 'litteä', mari loč|er mm. 'matala' ( $\mathrm{SMJ}_{3}$ v. s. ločer); vrt. sm. lattea.

Mikäli Saarikivi (henk.koht. keskustelu; Saarikivi 2006b: 56) on oikeassa johtaessaan Kenozeroon laskevan joennimen Poča ehdottamastaan kantauralin sanasta *puca $>*$ puča-s $>$ sm pudas : putaan, on meillä mahdollisesti vielä kolmaskin 
esimerkki affrikaatan säilymisestä. Saarikivi voi hyvinkin olla oikeassa, sillä sana poča esiintyy Pohjois-Venäjällä myös nimien perusosana ja venäläisenä murresanana. Esimerkkinä voi mainita lahden nimen Njuh|poča (Matveev 2004: 160). Kenozeron Poča-joessa ei ole sellaista pudasta, jossa sivuhaara palaisi pääjokeensa, mutta siihen liittyvässä joenomaisessa järvessä on hyvin pitkiä pääuomasta erkanevia lahtia (kartta 5), joista eteläisin on muinoin saattanut palata Poča-joen pääuomaan. Suomen pohjoismurteissa pitkiä umpilahtiakin voidaan kutsua putaaksi $\left(\mathrm{SSA}_{2} \mathrm{~s}\right.$. v. pudas). Tällaisia ovat esim. Alapudas (Oulu), Yläpudas (Juuka), Hepopudas (Lieksa), Isopudas (Rovaniemi), Luokkipudas ja Verkkopudas (Ilomantsi). Esimerkiksi Volgalla ja Oka-joessa on valtava määrä juuri tällaisia pitkiä lahtia. Ehkä tämä onkin putaan alkuperäinen merkitys. Tähän viittaavat sekä Onega-joen vesistöalueella esiintyvien - рос̆a-perusosien topografia että Onega-joen vesistöalueen venäjän murresana potča, počča, potša, poča 'vanha joenuoma, lahti, joen haara' (Matveev 2001: 222). Ei kuitenkaan ole varmoja todisteita siitä, että sana poča kuului paikallisen itämerensuomen sanastoon. Maastoterminä se kuitenkin esiintyy juuri Onegajoen vesistöalueella. Mikäli taustalla on sana $p u d a-s<*$ puča, muodostaa ensitavun vokaali ims. $\left\langle u>\right.$ mutta venOnega $<_{O}>$ määrätynlaisen äänteellisen ongelman. Yksi vaihtoehto onkin, että poča oli Onegan vesistöalueella paikallisesta merjalaiskielestä saatu lainasana. Merjalaisalueilla esiintyy sellaisia nimiä, kuten: Poč|ega (GBO 215) ja Poče|boš (GBO 206). Tällöin taustalla voisi olla merjan *poč(V) < sm.perm. *ponč 'häntä, perä' > mari pačlpoč, udm bǐz, komi běž.

Mullonen huomauttaa, että myös Karjalassa esiintyy sellaisia lahtien nimiä,joissa esiintyy nimikanta Poča-, Pod'ža-, Poža-. Hän (Mullonen - Zaharova 2013: 153-154) ehdottaa, että taustalla olisi saamen sana saP boaššo $(<\mathrm{ksa}$ *pōššō) 'kodan peräosa' $\sim$ saameOnega *počja (näin myös Helimski 2006: 122-123). Lehtiranta (2001: 106) useimpien muiden ohella katsoo, että ksa *pōššo $\sim$ sm pohja. Vastaavanlaisia rinnastuksia ovat esim. saP aššo $\sim \operatorname{sm}$ ahjo $<$ kgerm *asjōn ja saP dušš $i \sim \operatorname{sm}$ tyhjä $<$ balt. = liet. tuščias 'tyhjä' (ks. SSA $1-3$; Lehtiranta 2001; Sammallahti 1989). Mahdollinen vertailukohde voisi myös olla sm asia $\sim$ ksa *aššē $<$ ??kgerm *uzandia $>$ ru ärende 'asia' ( $\mathrm{SSA}_{1}$ s. v. asia). Epävarmana on myös esitetty sm vihja-ta < kgerm *wīsja$\left(\mathrm{SSA}_{3}\right.$ s. v. vihi). Suomessa esiintyvä - hj- palautuu siis *sj- tai *šči-yhtymään tai viimemainitussa epävarmana $<*$ z, siis joka tapauksessa sibilanttiin eikä affrikaattaan. Vastaavasti saamessa - ̌̌š- näyttäisi syntyneen originaalista, jossa on ollut sibilantti + $j$ tai $i$. Näin ollen Helimskin ja Mullosen ehdotus juontaa poča saamesta on mielestäni äänteellisesti haastava, koska esimerkkejä *čj tai $* \check{\zeta} j>\operatorname{sm} h j \sim$ sa $\check{s} s$ ei esiinny. Tosin emme tiedä, millaisia äänteellisiä lainalaisuuksia tarkalleen esiintyi ns. parasaamessa.

Venäjän substraattisanojen vokaalien välisten klusiilien $* \mathrm{t}>d, *_{\mathrm{k}}>\mathrm{g}$ ja $* \mathrm{p}>b$ soinnillistuminen vastaa usein livvin, lyydin ja vepsän soinnillistumista, mutta myös tapaa, jolla venäjä on yleensäkin substituoinut itämerensuomen soinnittomia konsonantteja (vrt. Rahkonen 2011: 223, taulukko 1). 


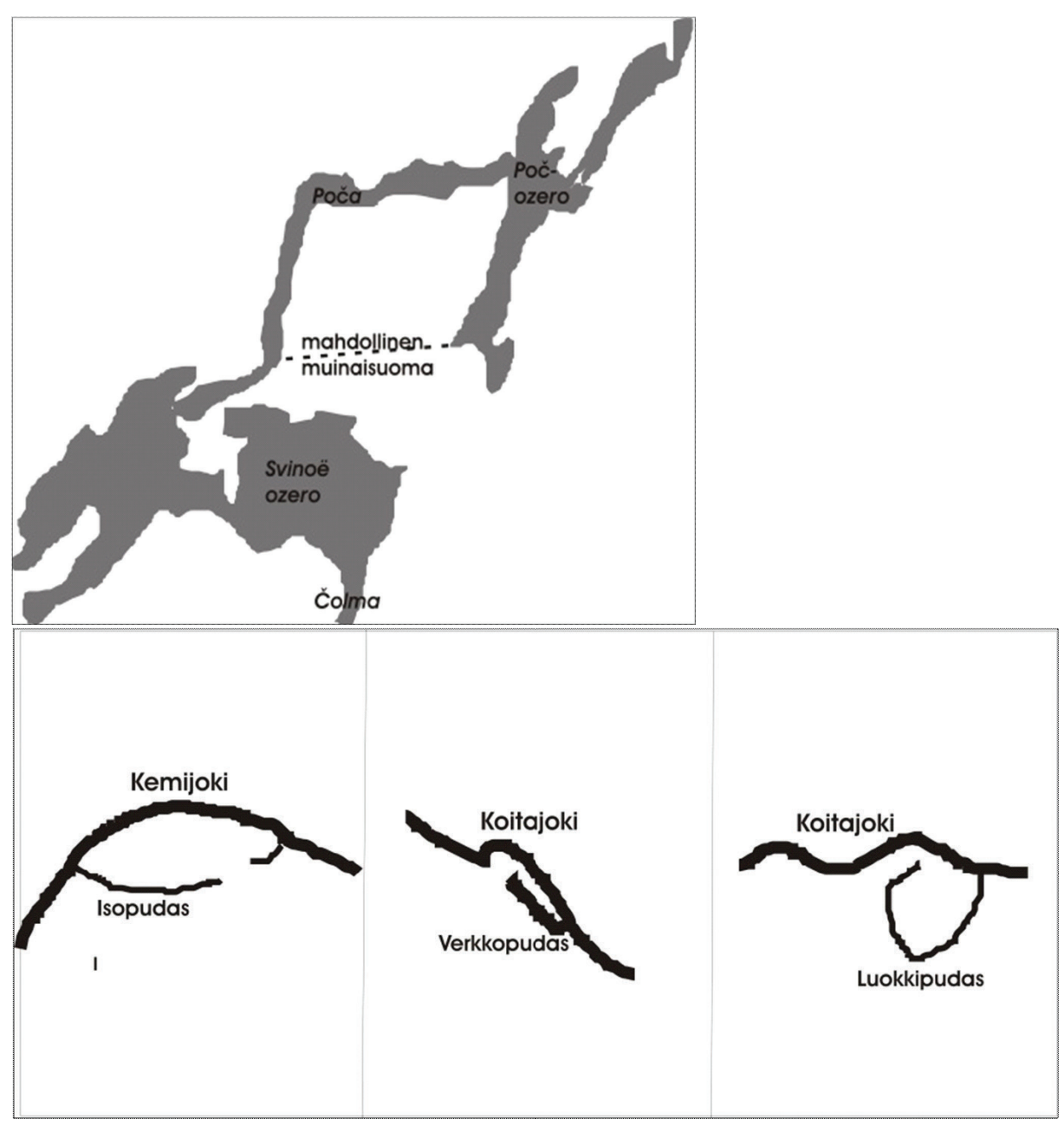

Kartta 5. Poča - Isopudas, Rovaniemi - Verkkopudas, llomantsi - Luokkipudas, llomantsi.

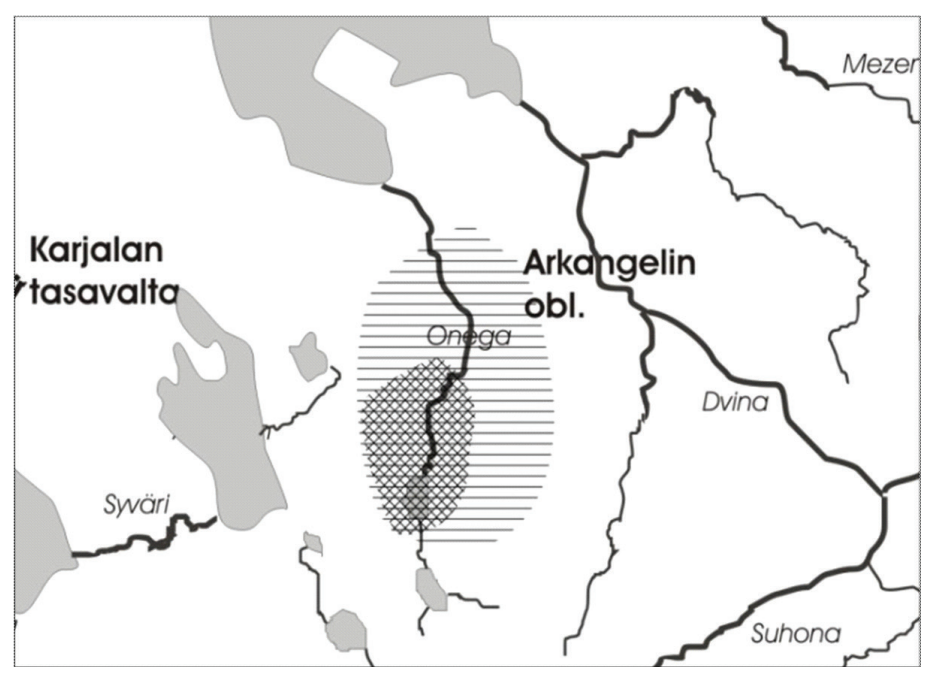

Kartta 6. Arkangelin venäjän lounaismurteen ydinalue ja periferia (Komjagina 1994: 227, kartta 193). 


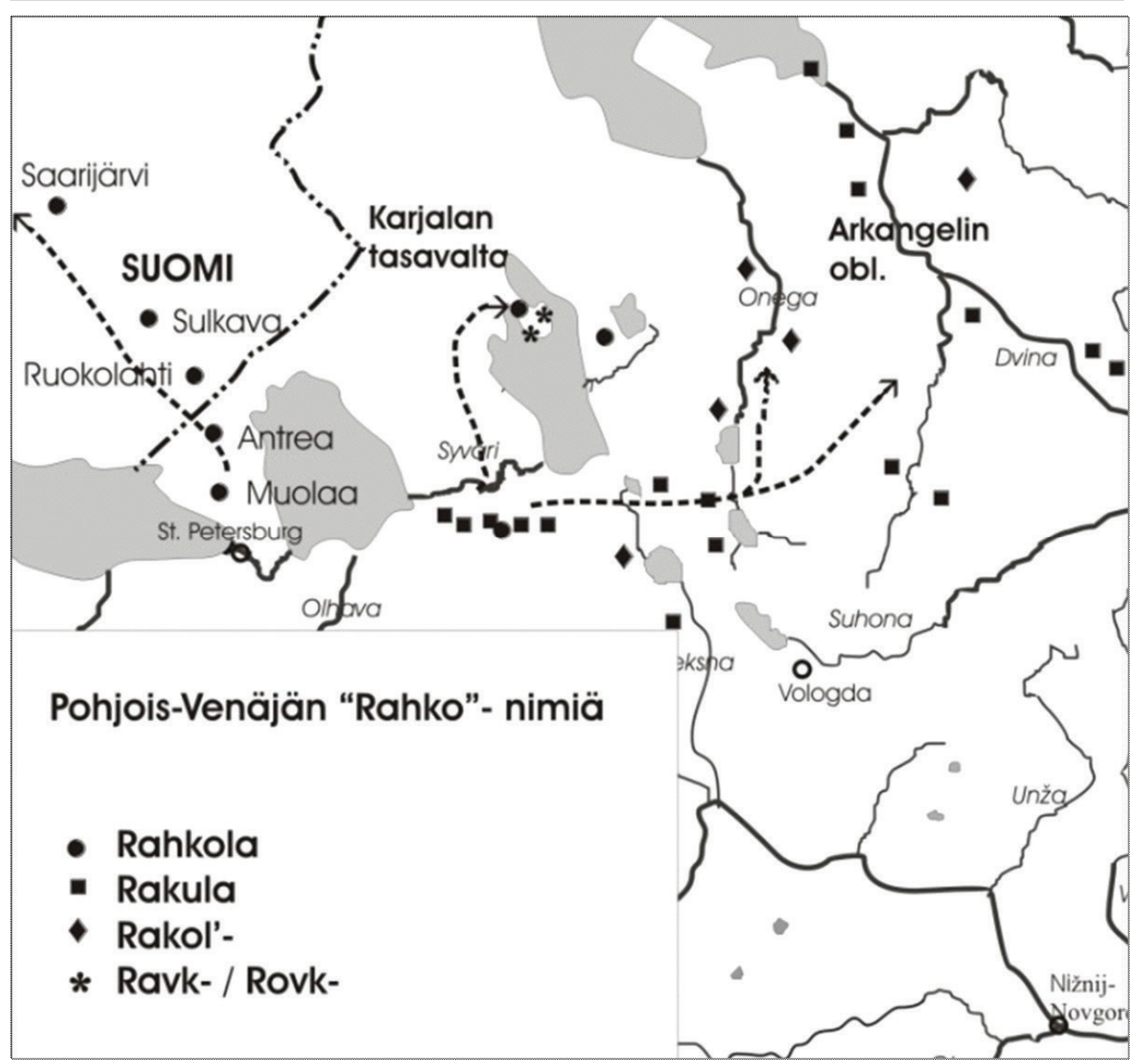

Kartta 7. Vepsäläis- ja karjalaisperäisten Rahko(i)la-oikonyymien levikki ja leviämissuunnat Pohjois-Venäjällä ja Suomessa.

Kargopolin-Kenozeron muinainen alkuperäinen itämerensuomi saattaa palautua aikaan (ehkä noin 700-1000 jKr.), jolloin selkeästi erottui vasta vain kolme myöhäiskantasuomesta polveutuvaa päämurretta: 1) pohjoismurre $>$ suomen länsimurteet häme mukaan lukien, 2) etelämurre > viro, vatja, eteläviro ja liivi sekä 3) itämurre, joista kehittyivät suomen itämurteet, inkeroinen, karjala ja vepsä (Terho Itkonen 1983) sekä mahdollisesti ns. taipaleentakainen Kargopolin-Kenozeron ja ehkä Vaga-joelle asti levinnyt itämerensuomi (ks. Rjabinin 1997: 133-134). Epäilemättä viimemainittu sai lisäaineksia myöhemmin ainakin karjalasta, josta kertovat Onegan varrella sijaitsevien kylien nimet Karel'skaja ja Podkarel'skaja hieman Konëvosta alavirtaan. Tästä vielä vajaa $20 \mathrm{~km}$ alavirtaan sijaitsee nyt jo autioitunut kylä Rakol'skie, jonka originaali mitä luultavimmin oli *Rahko(i)la. Tämä nimityyppi vuorostaan vaikuttaisi Rahko(la)-nimen yleisten kulkureittien kannalta mieluummin vepsäläiseltä kuin karjalaiselta (kartta 7; ks. myös Mullonen 2008: 153-154). Näin muodoin myös vepsäläinen muuttovirta näyttää todennäköiseltä. 
Oletettavinta kuitenkin on, ettei Kargopolin-Kenozeron alueella alun perin puhuttu itämerensuomi ollut sen paremmin karjalaa kuin vepsääkään, vaan aivan oma äänisentakainen itäinen murteensa. Selkeä itäisiä itämerensuomen ryhmiä keskenään äänteellisesti toisistaan erottava tekijä esiintyy sanassa lúda, jonka originaali venäjän substituutiosääntöjen pohjalta lienee karjalan, livvin ja lyydin tapaan -uo:1linen (siis *luoto tai *luodo) eikä arkaainen *looto, jota lähellä vepsän lodo on. ${ }^{5}$ Koska vepsän sana ei siis viittaa venäjän murresanan edellyttämään diftongiin, voi KargopolinKenozeron seudun itämerensuomen katsoa tässä suhteessa muistuttaneen enemmän karjalaa. Toisaalta nimi Hosima vuorostaan viittaa vepsän kaltaiseen diftongittomaan asuun *hoosia > ve hoźj $\left(\mathrm{SSA}_{1}\right.$ s. v. huosia). ${ }^{6}$ On kuitenkin huomioitava, että emme tiedä miltä aikakaudelta venäjän murresanat ovat peräisin. Joka tapauksessa terminus post quem on noin $1000 \mathrm{jKr}$., koska slaavit laajemmassa mitassa eivät sitä ennen olleet saapuneet kyseiselle seudulle. Seudun itämerensuomi on luultavimmin sammunut samoihin aikoihin kuin läheiseltä Vodlajärven alueeltakin. Tämän ovat eräät tutkijat päätelleet tapahtuneen paikoin mahdollisesti 1700-luvulla tai jopa hieman myöhemminkin (Loginov 1999: 107-108; Mullonen 1995: 196-197).

\section{Kargopolin ja Kenozeron alueen vesistönimistö}

\section{I. Kargopolin alue}

Kargopolin alueen nimistöön tässä tutkimuksessa on otettu kaikki suuremmat Lačajärveen ja Onegajokeen laskevat vedet alajuoksulle Kenajoelle ja sitä ylävirtaan Važa-joelle asti. Nimistö on suurimmalta osalta kerätty Proničevan (1996: 37-38) jokien nimiluettelosta ja GUGK/Kotlas-kartasta. Monien nimien alkuperäkieli jää selvittämättömäksi, mutta seuraavassa esittelen selvimpiä tapauksia:

Itämerensuomalaisia hydronyymejä (SSA I-3; KKS livvin osalta)

Čur'ega - ka ve tšura 'puoli, syrjä' tai ve čuru 'sora' + ega $<$ jogi $\|$ vrt. Kalima 1915: 242; Matveev 2004: 180

Hosima; Bol. \& Mal. - smI huosia(korte) | ka huosja 'kangaskorte | ve hoźj 'korte' + formantti -ma

Kalist $\mid$ oe $\mid$ ozero - vrt. Suomen Kalist $(V)$-nimistö (NA) $)^{7}+$ ims -oja tai ven neutrin tunnus -oe

Karbov|ručej - ve karbaz 'haapio' + ven vanh. genetiivi -ov \| vrt. Matveev 2004: 176

Keng|ozero - ka kenkä 'kenkä, saapas' | ly ve keyg id.

Kulta; Verh. \& Nǐ̌. - ka kulta 'kulta(metalli)'; metallien värit ovat yleisiä nimeämismotiiveja; vrt. hopea-, vaski-. Huomioitava olisi myös suomalais-permiläiseen kantakieleen palautuva verkkokalastamista tarkoittava kanta *kult- (Sam-

5. Vrt. vanha venäjä *Suomi $>C y м b$ [Sum'] ellei ole peräisin ajalta, jolloin suomessa diftongistuminen ei ollut vielä tapahtunut, vaan käytössä oli asu *Soomi.

6. Kansalaisen karttapaikka tuntee Suomessa 198 huosia-nimeä.

7. Kalistanluoma [oja; Kurikka], Kalistenoja|naukee [niitty; Huittinen] (Kansalaisen karttapaikka). 
mallahti 1988: 544) > *kulte > sm kulle : kulteen 'heittoverkko'. Normaalisti tosin odottaisi venäläisen adaptaation seurauksena asua Kulda. Näyttää kuitenkin siltä, että adaptaatiosäännössä $* \mathrm{t}>d$ (mm. Rahkonen 2011: 223, taulukko 1) esiintyi horjuvuutta ehkä adaptoinnin ajankohdasta riippuen; vrt. jäljempänä Šold- ja Šolt-nimet tai Poldoma- ja Poltoma-nimet.

Lača Lače oz. - livvi lattšu 'lattea, matala' (KKS s. v. lattšu)| ve lačak 'litteä' (Zajceva - Mullonen 1972: 269) | mari loč|er 'matala' $\left(\mathrm{SMJ}_{3}\right.$ s. v. loč|er) || vrt. myös Makarova 2012: 442; Popov 1973. Sen sijaan Helimskin (2006: 121) esittämä laho-etymologia on aivan mahdoton hyväksyä jo pelkästään semanttisistakin syistä. Minkään suuren järven nimi ei koskaan perustu sanaan 'laho'. Nimeämisperusteena on voinut olla järven tavattoman alava ja tasainen ympäristö tai myös järven poikkeuksellinen mataluus.

$\boldsymbol{L} \boldsymbol{e j} \boldsymbol{j} \mid \boldsymbol{u} \mathbf{\boldsymbol { s }} \boldsymbol{a}$ - livvi leiby 'leipä' | ly ve leib 'leipä, leipävilja + formantti -uš <*-us ja ven feminiini - $a \|$ vrt. Makarova 2012: 444

Lovz|anga - ka lausa 'tasainen' | livvi lauza 'tasainen' | vi laus 'loiva, avoin'

Nimen'ga, Nimen'gskoe oz. - ve ńima ńim 'lima, muta' tai nim- < ve *ńem 'niemi' (ks. Mullonen 2002: 63)

Njandoma < *Mjandoma - ka (paikoitellen) mändy 'mänty' | ly mänd(ü) id. ve mänd id.

Palom $\mid \boldsymbol{k} \boldsymbol{a}<$ *Palomaa - ka palo 'palanut paikka, poltettu kaski' | ly palo 'kaski' | ve palo 'kaskenpoltto' || vrt. Matveev 2004: 152

122, 133

Pert - livvi pertti 'pirtti' | ly pert'(ti) id. | ve peŕt' id. || vrt. Matveev 2004: 115,

Poldoma - ka palte (KKS s. v. palte) || Saarikivi (2006b: 34) esittää vastaavan etymologian Arkangelin alueella esiintyville kahdelle Poltoma-joelle. Viteleen karjalan murteessa palte 'karin reuna' (SSK s. v. palte) antaa hyvän nimeämisperusteen.

Vaškinec - kaP vaški 'vaski' | ly vašk 'vaski, kupariraha' | ve vaśk' 'vaski'

Vargas - ly ve vargaz 'varas', vargastada 'varastaa' || vrt. Saarikivi 2006: 36

Lisäksi löytyy muutama itämerensuomalaista perua oleva asutusnimi kuten Nokola < *Nokkola, Hak $\mid u j<*$ Hako-oja (ka hako, ly ve hago), Kuče $\mid$ palda < *Kuuttša|palte 'tervanpolttorinne' (ka kuuttša 'miilu', palte 'mäen rinne', sm.murt. kuutsa id.) tai *Kuuttšapeldo; ks. *e a (Matveev 2004: 206-207). Mullonen (henk. koht. informaatio) huomauttaa, että ka kuuttša on myöhäinen venäläinen laina ja siksi epäsopiva tähän yhteyteen. On kuitenkin huomattava, että alueella todennäköisesti puhuttiin itämerensuomea aina 1700-luvulle asti, joten myöhempikin laina tulee ymmärtääkseni kyseeseen. Toisaalta Suomen murteissa esiintyy myös kuuts-kantainen linnun nimi 'kuukkeli' (SMS s. v. kuutsanka/o, kuutsikas). Joka tapauksessa nimen jälkimmäinen elementti -palda on itämerensuomea.

Vuonna 1873 keisarillisen Venäjän virkamiesten laatimassa kirjallisessa tiedonannossa Spiski naselennyh mest Rossijskoj imperii po dannym za 1869 god mainitaan, että Lačajärven ympäristössä sijaitsi joukko venäläistyneiden tšuudien kyliä. On hieman outoa, että edellä mainitusta suhteellisen viimeaikaisesta kirjallisesta maininnasta huolimatta Kenozerolla kukaan haastatelluista ei muistanut etnonyymiä tšuudi, toisin kuin esimerkiksi Pinegalla (Saarikivi 2006: 11). Kargopolin seudulla en suorittanut haastattelukyselyjä. 
Parasaamelaisia hydronyymejä (kantasaame Lehtiranta 200I)

? Jelima $<$ *Elima $\sim$ ksa *elmē 'ilma', nimistössä 'ylä-'

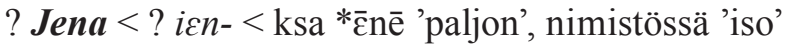

? Jut'ega $<$ ? ksa *jotē 'kulkea, judata'

? Poržala $<$ ? ksa *poršō 'kuohua'

? Sora $<\mathrm{ksa}$ *sōrē 'haara'

Edellä esitetyistä nimistä on kuitenkin huomautettava, että merjalaisalueilla esiintyy sellaisia hydronyymejä kuten Jelomza (AJO 40A2) ja Jel'|šma (AKO 13B1), joten myös kargopolilainen Jelima aivan kuin myös Jena (vrt. merjalaisalueitten Jen|ka, AJO 118B3, ja Jen $\mid d y \check{\text {, }, ~ A K O ~ 124 A 3) ~ s a a t t a v a t ~ o l l a ~ a l k u p e r a ̈ l t a ̈ a ̈ n ~ m e r j a l a i s i a ~ h y d-~}$ ronyymejä. Kargopolin ja Valkeajärven alueilla usein nimissä esiintyvä appellatiivi sora voi olla saamelaislähtöinen (ksa *sōrē 'haara), mutta myös venäjän okanjen vaikutuksesta $* \mathrm{a}>o$ on mahdollinen, jolloin originaali on *sara (ks. Mullonen 2002: 47-49; Matveev 2004: 184). Myös Poržala-nimellä on vastineita merjalaisalueilla (ks. jäljempänä).

\section{Merjalaistyyppisiä hydronyymejä8}

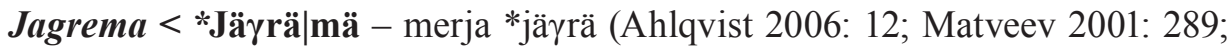
Rahkonen 2012: 38, taulukko).

Jugon|dǐs - Merjalaisalueella -diš on yleinen topoformantti.

Kinema - merja *kine ? 'töyry, harju'; vrt. kaupungin nimi Kine|šma Volgan rannalla Kostroman alueella (AKO 186B2) ja joen nimi Kine|šem $\mid k a$ (AKO 186B2) sekä hydronyymit Kina|r (GBO 187), Kine|l' (GBO 200) Okan vesistöalueen merjalaisalueella; ks. myös merjalainen asutusnimi Kinela (Ahlqvist 1998: 20-22).

Lëkšma, Lëkšm|ozero - Merjalaisalueilla löytyy vastaavuuksia Lekša (AJO 15B1), Lekša (AKO 25B2). On mahdollista, että myös merjassa esiintyi sporadisesti sananalkuisen vokaalin heittymistä niin kuin joskus mordvassakin; esim. md *uskal(V) > skal 'lehmä' (Sammallahti 1988: 552) tai md *ińe ški > ńiške 'taivaan jumala' (MWB 3 s. v. ńiške). Tähän vedoten Arja Ahlqvist (1999: 626) on esittänyt, että merjalaisalueen keskeisen järven nimi Nero oli alkuaan *In-er(V) 'isojärvi' (mielestäni mieluummin *En-er, ks. jäljempänä kohta Onega). Tällöin Lëkšma-nimi olisi voinut olla alkuaan *Ile|kš|ma 'yläjoki'. Lëkšmozero on todellakin ylimmäinen vesi, joka sijaitsee vedenjakajalla. Nimeä voisi verrata Suomi-Karjalan Lieksa-nimeen, joka on selitetty saamelaisperäiseksi (? lieksa < saP leakšá 'soinen laakso (tunturissa)'; SPK s. v. Lieksa; Sammallahti 1989 s. v. leakši leakšá). Lieksanjoki on kuitenkin iso ja pitkä, joten motiivi tuntuu kaukaa haetulta. Lisäksi Suomen pohjoissaamen puhuma-alueella ei esiinny yhtäkään Liekšá-nimeä (NA). Täsmälliset merjalaiset vastineet Ylä-Volgalla ovat painoarvoltaan vakuuttavammat kuin hieman epäilyttävä saamelainen vaihtoehto.

8. Kyseessä voi olla jokin merjan pohjoinen lähisukukieli (ks. Rahkonen 2012: 19-27). 
Pežma - vrt. Kostroman alueella Peženga (AKO 36B2). Makarova (2012: 500) on listannut nimen, muttei löytänyt etymologista ratkaisua. Ehkä Pežma < *Požma tai Pežma, jolloin taustalla voisi olla sana, jota vastaa permiläinen udm. pož ja komin pežž 'likainen'. Venäjä on kaikkialla substituoinut *e $>e$.

Porma - vrt. Jaroslavlin alueella Kostroman lähellä Porem|ža < *Porma|ža

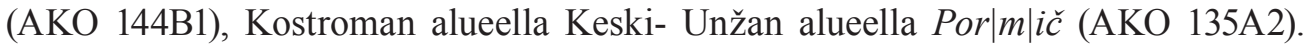
Mahdollisesti nimikanta vastaa suomen sanaa puro, vaikkakaan tällä ei ole vastineita tunnetuissa sukukielissä. Tällöin se ehkä voisi olla merjaan tullut indoeurooppalainen lainasana, ? merja *por(V) 'joki, puro'; vrt. skyytin porota 'joki' (Gordeev 1990: 91).

Poržala - Merjalaisalueella vastineita Kostroman alueen Porž|nja (AKO 177A1) ja mahdollisesti Porz|nja (GBO 222) sekä Porz|inskoj (GBO 227). Myös formantti -la on hyvin yleinen merjalaisnimistössä. ${ }^{9}$ Määriteosan * porž(V) merkitys on tuntematon, ellei ole esiarj. *porśos (SSA 2 s. v. porsas) ? > merja *porź- tarkoittaen metsäsikaa. Mullonen (henk.koht. informaatio) ehdottaa, että taustalla on saamen sana ksa *poršō 'kuohua', mikä sekin on hyvin varteenotettava vaihtoehto.

Sara - Saran vuorilinna (Sara-joen varrella) on merjalaisalueiden merkittävin arkeologinen löytöpaikka (Leont'ev 1996: 320). Nimivastaavuuksia esiintyy Okan vesistöalueella Sara (GBO 194), Sara|ev (GBO 207), Sara|nga (GBO 254). Kargopolin alueella taustalla voi kuitenkin olla myös itämerensuomalainen originaali ly sara, sarahein 'sara(heinä)' tai ve sara 'haara'; näin myös merjassa *sara 'latvajoki'.

Sonika ? < * Sonjega - Nimikanta son- on yleinen merjalaisalueilla. Taustalla lienee merjan sana *so(o)ni < sm.perm. *sooni 'suoni, vesireitti' (Sammallahti 1988: 548); vrt. md san id. (MWB 4 s. v. san): Son|ža (AJO 37B3), Sono|hta (AJO 62B1), Son|'ga (AJO 65B4), Son $j a$ (AJO 53A2), Son $\mid b a z$ (AKO 197B2), Son $\mid b a$ (GBO 216, 220); vrt. Suomen Eura ja Aura < kgerm *ēprā / *āpra 'suoni, vesireitti' (Koivulehto 1987: 36) Oder Saksassa.

Šor|šma (2 kpl) - Merjalaisalueilla esiintyy useita vastineita, joilla on nimikanta *šor; vrt. mari šor 'suo', udm šur 'joki', komi šor joki': Šor|ša (GBO262), Šora (GBO 214), Šra (AKO 181B1), Šoro|šma (AKO 13B1).

Šuja; Bol. \& Mal. - Merjalaisalueilla on useita vastineita: $\breve{S} u j \mid k a$ (GBO 120), Šuj|skoj (GBO 220), Šujskoe|ozero, Šuj|ga (AJO 13B3), Šuj|skoe oz. (AJO 13B3), Šuja (AKO 105A3). Alkuperäinen merjan sana lienee *śuj 'pitkä, kapea lahti'. Tätä perustelen silmiinpistävän topografisen säännönmukaisuuden lisäksi saamelaisilla vastineilla. Onegajoen niskalla on Lačajärvessä pitkä, kapea lahdenomainen vesialue, jonka eräs niemi on nimeltään $\breve{C} u j$. Vastaavasti Karjalan Säämäjärvessä on Pohjalahti, johon liittyy niemi nimeltä Čuj|navolok (TKRK 95). Vodla-järvessä on Vavdipol'skaja (*Valdi-) lahta. Siihen liittyvässä niemessä sijaitsee asutus nimeltä Čuja|la. Niemien nimet saattavat heijastaa lahtien vanhoja nimiä tai palautua mahdolliseen parasaamelaiseen sanaan $\check{c} u j(V)$ 'pitkä ja kapea'. Nimet voisivat selittyä saamelaisina vastineina merjan sanalle *śuj, jolloin säännönmukaisesti saamessa $* \dot{s}>\dot{c}>$

9. Formantilla -la on merjalaisalueilla joskus variantti -lja <*läj <*läkä 'joki' (GBO). Myös komilaisalueilla esiintyy formantti -la (vrt. Syso|la, Vin|la jne.), joka on saattanut kehittyä komin sanasta jel 'puro'. 
č. Saamessa esiintyy pitkää lahtea tarkoittava sana saI čuája (Sammallahti-Morottaja 1993 s. v. čuája), jossa on kylläkin hyvin vaikeasti selitettävissä oleva -á-vokaali. Matveev (2004: 158) on epäuskottavasti johtanut $\breve{S} u j$-nimet livvin sanasta šuo.

Uhta, Uht|ozero - Tällä nimityypillä on lukuisia vastineita merjalaisalueilla: Uht|oma (GBO 214), Uht|ohma (GBO 217), Uhta|nka (AJO 66B2), Uhta-Toržok (AJO 60A3), Uht|oma (AJO 103A4), Uht|oma (AJO 19A1), Uhta (AKO 60A3), Uhta (AKO 86A1), Uhtlingir AKO 171B2). Taustalla on merjan sana *uxt(V) 'kannas, vetotaipale' (mm. Mullonen 2002: 208-215; Rahkonen 2013a: 10-17).

Vandǐs - Tällä nimityypillä on muutamia vastineita merjalaisalueilla: Vandǐs $\mid k a$ (AJO 53A3) Vandǐš $\mid k a$ (AKO 150A3). Taustalla lienee sanajuuri *van(V), sillä jälkikomponentti -diš näyttää olevan formantti, joka on liitetty moniin erilaisiin nimikantoihin (Jugon $\mid$ dišs, Sor $\mid$ diš, Vo|dišs, Jen $\mid$ dǐs $)$; vrt. Suomen Vanajavesi; vrt. myös vana ka 'railo, ura' | veK 'rotko' (SSA 3 s. v. vana).

On nimistönkin perusteella ilmeistä, että Kargopolin ja merjalaisalueiden välillä on vallinnut läheinen yhteys. Jopa itse nimi Kargopol' saattaisi olla johdettavissa merjan kielestä. Koska Lačan seutu on "tuhansien kurkien maa", voisi ajatella, että kurki olisi ollut asutuksen nimeämisperuste. On mahdollista, että merjassa tai jossain sen lähisukukielessä on esiintynyt sana *korgə 'kurki', josta myöhemmin itämerensuomen vaikutuksesta *kargo. ${ }^{10}$ Tätä tukee äänteellisessä mielessä mordva, jossa mdE kargo 'kurki' ja saame ksa *kōrke 'kurki' < *kark(i). Jaroslavlin alueella esiintyy hydronyymi Karga|č (AJO 18B1) ja asutusnimi Karganovo (AJO 55B1). Kargač tosin saattaa olla peräisin venäjän murresanasta kargač 'suo tai rantaheinää kasvava alue' (ks. Makarova 2012: 393-394). Toisaalta - č on yleinen topoformantti Pohjois-Venäjällä (Matveev 2001: 247-248). Kostroman alueella vuorostaan löytyy kaksi Kargu|l'-nimistä jokea (AKO 61B2, 132B3). Toisen tavun vokaalin vaihtelu $o$, $a, u$ saattaa johtua siitä, ettei venäjässä ole vastinetta redusoituneille vokaaleille $(\hat{\partial}, \partial)$. Jälkikomponentti -pol on mitä yleisin merjalaisissa asutusnimissä. Liudentunut pol' saattaa olla venäläistä kansanetymologiaa < póle 'pelto'. Useimmat tutkijat katsovat merjan sanan *bol tai *pol merkinneen kylää ja olevan etymologisesti yhdistettävissä itämerensuomen sanaan *poole > puoli (mm. Ahlqvist 2001: 152; Matveev 2001: 209). Joskus on originaaliksi esitetty itämerensuomalaista sanaa Karhunpuoli (mm. Višnevskaja - Gorohov 1997: 434). On kuitenkin muistettava, että sana karhu oikeastaan esiintyy vain suomen kielessä ja pohjoiskarjalaisessa runoudessa. Tavallisesti itämerensuomen itäisessä ryhmässä käytetään sanaa ka kontie (livvi kondie, ly końd $\bar{\imath}$, ve końd'̄̄).

Eräänä vaihtoehtona voisi ajatella nimen liittyvän Suomen karkea-nimistöön (NA), joskaan en keksi hyvää nimeämisperustetta tälle selitykselle. Karjalassa esiintyy sana karkea 'kylmä, tuulinen sää' ( $\mathrm{SSA}_{1}$ s. v. karkea), mikä jotenkin voisi sopia Kargopolin aukeiden lakeuksien tuulisiin olosuhteisiin. Mullonen (henk.koht. informaatio) muistuttaa, että Karjalassa puoli-asutusnimien määriteosana tavallisimmin esiintyy henkilönimi, mikä voisi olla kyseessä myös Kargopolin tapauksessa. Kylien nimethän usein perustuvat antroponyymeihin; esim. edellä mainittu Rahko(i)la.

10. Merjassa esiintyi äänteenmuutos *a $>o$ (Rahkonen 2012: 17). 
Tässä yhteydessä Mullonen ehdottaa henkilönimen taustaksi ims. sanaa karhea, josta esim. Suomen Karho- ja Karhi- kylän- tai talonnimet (ks. NA) sekä vepsän Karhil tai Karjalan Karhol'a.

Mullonen (2002: 244-246) ja häntä varauksin seuraten Kuzmin (2013: 108, kartta 3,111) ovat tulkinneet Jagr-nimet "järvienvälisellä alueella" saamelaisiksi siten, että $*_{v}>g$. Matveev (2001: 307-308 ja kartta 6) vuorostaan on tulkinnut niiden kuuluneen ns. "pohjoisen suomalaiskielen" merjaa lähellä olevaksi sanaksi erottaen ne saamelaisista javr-nimistä. Keskusteltuani aiheesta Vologdan alueen venäjän murteeseen erikoistuneen slavisti Jouni Vaahteran kanssa, piti hän Mullosen esittämää kehityskulkua $*_{v}>g$ epätodennäköisenä (sähköposti 14.9.2014). On totta, että Syvärin vesistöalueella esiintyy sellaisia nimivariantteja kuten Irb $\mid$ ozero $\sim \operatorname{Irg} \mid$ ozero $<$ *Hirvjärv, Koiguši Koivuši < *Koiv-, Ladv|ozero Ladg|ozero < *Ladvjärv, Savozero Sagozero < *Savjärv, Jarb $\mid$ oj Jarg|oj < *Järvoja (Mullonen 2002: 68). Näiden *v ei kuitenkaan alkuperäisessä nimikannassa (*hir-v(i), *koi-v(u), *lat-v(a),

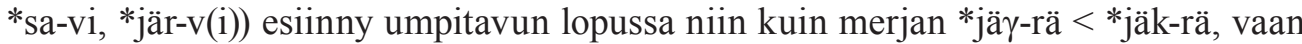
tavunalkuisessa asemassa. ${ }^{11}$

Myös Saarikivi (2004: 216) on pohtinut tätä kysymystä käyttäen esimerkkinä historiallisissa lähteissä dokumentoidun Pinegan alueen kylän nimeä *Kegrola (v. $1137)>$ Kevrola (nyk.). Tämä esimerkki on kuitenkin siitä hankala, että periaatteessa kyseessä voisi olla nimen *Kevrola venäjän kielen oikeinkirjoituksessa tapahtunut muutos $г>$ в $[g>v]$ (ks. kuitenkin edellä), mutta luultavammin Pinegan itämerensuomessa on tapahtunut äänteenmuutos kegr-> keur-; vrt. suomen *mäkrä > mäyrä.

Mielestäni Matveev oli lähellä totuutta, vaikkakin esitti hieman epämääräisen termin северно-финский язык 'pohjoinen suomalaiskieli' (2001), johon Saarikivi (2006b: 52-53) on suhtautunut hieman kriittisesti. Kuten Saarikivi on osoittanut, on Venäjän Pohjolassa itämerensuomen lisäksi puhuttu ainakin kahta uralilaista substraattikieltä. Toisella oli yhtäläisyyksiä merjan kanssa ja toinen oli arkaainen uralilainen kieli, mahdollisesti jonkinlaista esi-itämerensuomea niin kuin hän (Saarikivi 2006b: 55) on arvellut. Epäilemättä alueella joskus puhuttiin myös jotain täysin tuntematonta paleo-eurooppalaista kieltä tai kieliä, mistä todisteena on koko joukko tunnetuille tai rekonstruoiduille uralilaisille kielille täysin vieraita nimikantoja. Lisäksi alueella on puhuttu jotakin saamea muistuttanutta kieltä (mm. Matveev 2001: 344-345; Mullonen 2002: 228-290). Rahkonen (2012: 19-27) on esittänyt, että pohjoista merjalaismurretta puhuttiin Valkeajärveltä itään Kubenan Suhonan alueella. Edellisten lisäksi Laatokan ja Onega-joen seudun välisellä alueella on puhuttu kieltä, joka on ollut ilmeisesti merjan läheinen sukukieli (Rahkonen 2012: 20-25, kartat 2, 3 ja 4). Myös Mullonen (MAG 1997: XIX; 2002: 214, 290-291) on viitannut ylävolgalaisiin yhteyksiin Syvärillä ja Karjalassa.

11. Itseasiassa venäjässä $g: n$ ääntäminen v:nä esiintyy lähinnä vain sanoissa ezo 'hänen (m.)', когo 'kenen (m.)', сего 'tämän' (yks. mask.gen.), того 'tuon' (yks. mask.gen.), этого 'tämän' (yks. mask. gen.) sekä yksikön maskuliinin genetiiveissä -его / -ого. Tuolloin ne ovat tavunalkuisessa asemassa. 
Onegan vesistöalueella esiintyvää opaakkia nimistöä

Kovža - Muualla: Vologdan alueella Kovž (AVO 25V4), Kovža (AVO 13G5, 54V3), Kovžinka (AVO 35B4), Kovžkoe oz. (AVO 13V5); Karjalassa Kovža (TKRK 78-Ä), Kouža|šari (TKRK 23-P). Matveev (2004: 83) ja Makarova (2012: 406) ovat katsoneet, että kyseessä on saamelaisperäinen sana; vrt. saP guovža (Sammallahti 1989 s. v. guovža), saI kuob'žâ 'karhu' (Sammallahti-Morottaja 1993 s. v. kuob’žâ). Äänteellisesti tämä on mahdollista, mutta saP ja saI sana ei rajallisen saamelaisen levikkinsä perusteella palautune kantasaameen, mikä tekee selityksestä epävarmemman (Lehtiranta 2001).

Ohto|nga $-<$ kantaural *ukti 'taipale, polku/tie'; ks. Rahkonen (2013: 17, kartta 9). Matveev (2004: 152) on tulkinnut nimen Ohtmatka merkitsevän 'karhunmatka'. Tosiasiassa sekä oht- että -matka kumpikin viittaavat kannakseen tai vetotaipaleeseen.

Onega - Muualla: Syvärin seudulla Ojatilla Onega (MAG 65), Pašalla Onega Onegost' (MAG 94); originaali voi olla ims *Enäjogi, ksa *ēnējoke tai merjalainen *En(ä)joga (ks. Mullonen 2002: 61, 281-282; Rahkonen 2012: 38, taulukko) 'Isojoki'.

Sijanga - Vologdan alueella ? Si|uč (AVO 71B4), Arkangelin alueella Sija (GUGK/Arhangel'), Kostroman alueella Si|bol (AKO 84A1); vrt. md sija, mari šij 'hopea', ? merja *sī 'hopea'. Tätä myös Makarova (2012: 552) on ehdottanut. Mullosen mielestä (henk.koht. informaatio) nimen Siuč taustalla voi olla myös ims. syvä. Syvärin vesistössä esiintyy venäläisissä adaptaatioissa vokaalien välisen v:n heittymistä, kuten esim. Sajmega $<*$ Savimägi, Saj|ručej <*Savioja (Mullonen 2002: 68), jolloin Sija $<*$ süvä voisi olla mahdollinen (-ja $<*$ ä).

Sondala; Bol. \& Mal. - ks. Rahkonen (2013: 35, kartta 24); vrt. ka sonto 'käyrä'. Mullonen (2002: 260-268) esittää selitykseksi ksa *sōnte 'leikata auki' (Lehtiranta 2001: 126) viitaten jokien virtaamiseen niihin liittyvien järvien läpi. Hänen esittämänsä tapaukset todellakin ovat tällaisia, mutta esim. Suomen suuret järvet Suontee ja Suontienselkä (johon Suonenjoki laskee) < *Suontee tai Heinolan Sonnanen eivät juurikaan tue tätä käsitystä.

Šaglas - Muualla: Vologdan alueella Šagras (AVO 77V4), Šaglanci ostr. (TKRK 47-P). Huom! Pohjois-Venäjän nimissä $l \sim r$ vaihtelu (Mullonen 2002: 65-66). On pantava merkille myös ilmeinen saamelainen deminutiivi *-nće nimessä Šagla|nci.

Šard|uša - Muualla: Vologdan alueella Šarden'ga (AVO 27V4), Karjalassa Šardola (TKRK 87-Ä), Šardom|ozero (TKRK 87-Ä), Šardom|ozero; Bol. (TKRK 101- Ӓ, Šardon|skie ostrova (TKRK 113-E), Onegajoella Šard|ozero (GUGK/Onega: G6); ? vrt. mari šordo 'hirvi' (SMJ s. v. šordo), mdE šardo (MWB s. v. šardo).

Šoltoma - Muualla: Syvärillä Ojatin latvoilla ? Šold|ozero, -ručej (MAG 40), Karjalassa Šelta, Šelt|ozero (TKRK 77-Ä), Šëltozerka (TKRK 124-E), ? Šold'järvi (TKRK 94-E).

Tihman'ga - Muualla: Vologdan alueella Tihla (AVO 48A2), Syvärillä Tihk|ozero (MAG 39), Onega-joella Tig|l|inskoe oz. (GUGK/Onega: E6), Tiht|ozero (TKRK 20-P). 
Važa - Muualla: Vologdan alueella Važa (AVO 47B6), Syvärin alueella Važ|ozero, Važozerka (MAG 14), Važena Važina (MAG 13), Važ|ozero (MAG 17), Važ|evskoe (MAG 60), Onegajoen alueella Važa (GUGK/Onega: E6), Važ|ozero (GUGK/Onega: G7 ja E5), Karjalassa Važenka oz. (TKRK 9-P), Važi|lambi (TKRK 82-E) < ? sm.perm. *voša 'haara' (Sammallahti 1988: 554); vepsässä esiintyy sana važu 'seiväs, johon vene tai verkko voitiin kiinnittää' (Zajceva - Mullonen 1972: 618). Mullonen (2002: 288-290) on pitänyt mahdollisena, että taustalla on (para)saamen sana *vaćo ksa *vuoččó 'kapea suo'. Tätäkään ei voi pitää aivan mahdottomana ajatuksena. Toki yksi mahdollisuus on johtaa nimi ims. sanasta vasa.

Edellä esitettyjä hydronyymejä esiintyy Kargopolin alueen lisäksi alempana Onega-joella, etelämpänä Vologdan alueella ja Syvärin vesistöalueella. Lisäksi niitä esiintyy Karjalassa etenkin Äänisen takana (Ä), mutta myös jonkin verran Karjalan Tasavallan eteläisellä (E) ja pohjoisellakin puoliskolla (P) Karhumäen tasa rajana. Mitään varmaa kielellistä taustaa näille nimille ei voi löytää. Sond- (Suont-) ja Ohtnimet $^{12}$ ovat levikiltään hyvin laaja-alaisia ulottuen aina Sisä-Suomeen asti. Näiden nimikantojen voisi arvella liittyvän varhaiseen länsiuralilaiseen $x$-kieleen, jonka lähtöalue oli juuri "järvienvälisellä” seudulla, mutta joka levisi tekstiilikeramiikan mukana länteen ja luoteeseen; ks. Rahkonen 2013: 162-173, 183 kartta 24.

Jotkut nimet on tässä esityksessä jätetty kokonaan esittelemättä, koska niille ei välttämättä voi osoittaa mitään varmaa levikkiin liittyvää laajempaa yhteyttä tai varmaa etymologiaa: mm. Svid', Sahar, Tazdanga, Jerman'ga, Komža, Korma, Marega. Jotkut voivat liittyä Valkeajärven etelänpuoliseen nimistöön, jonka markkerina on -buj, -boj <*ßoj, kuten Tom|boj ja Voja (ks. Matveev 2001: 256-261). Jotkut ovat moniselitteisiä ja niillä voi olla vastineita monissa kielissä kuten Šum|ručej, Vad'ja ja Karas.

\subsection{Kenozero}

Kenozeron nimistöä ovat keränneet Derjagin - Derjagina - Manihin (1987). Myös Matveev (2004: 157-165) on käsitellyt aihetta, joskaan ei aivan perusteellisesti. Viimeksi aiheesta on kirjoittanut Mullonen (Mullonen - Zaharova 2013). Verrattuna Kargopolin seutuun on substraatti(vesistö)nimistö Kenozerolla selvästi itämerensuomalaisempaa. Merjalaistyyppinen nimistö puuttuu lähes kokonaan. Myös saamelaisia ja tuntemattomasta lähteestä peräisin olevia nimiä on melko vähän.

\subsection{Kenozeron hydronyymit}

Itämerensuomalaiset järvien ja jokien/purojen nimet (ims. nimikantojen merkitykset SSA ja livvi KKS):

Kang|ozero; Bol’šó \& Málo - sm ka kangas | ly kaygas | ve kaygaz; esim. Syvärillä Kurban vesistössä Кангозеро Kangazjärv (MAG 37)

12. Oht-nimet Onegan vesistöalueella alueella epäilemättä palautuvat kantauralin sanaan *ukti 'vetotaival' (Rahkonen 2013a: 14-17). Näyttäisi, että niiden latvoilla topografian perusteella on ollut vetotaival. 
Laht|ozero; Bol'šó \& Málo - sm livvi lahti | ly ve laht

Noid|ozero; Bol’šó \& Málo - sm ka noita $\mid$ ly noide | ve noid

Pëd|ozero; Bol'šó \& Málo - sm ka petä-jä | livvi pedäi | ly ve pedai

Pihk|ozero; Bol'šo \& Málo - sm ka pihka | ly pihk(e) | ve pihk 'pihka, tiheä havumetsä' | veE pihk 'mänty'

Vahk|ozero' ${ }^{1}$ - sm ka vehka | ly ve vehk 'raate'; ks. *e > a (Matveev 2004: 160; Mullonen 2002: 64)

Vahk|ozero ${ }^{2}-\mathrm{id}$.

Gám|ozero - ? ims hämä- 'synkkä, pimeä, utuinen' (näin myös Mullonen 2013: 158-159)

Karang|ozero - sm karanko, karanka 'pystyyn kuivunut nuori puu, kuivunut oksa, riuku, seiväs' | ka karankokuusi 'pitkä ja hoikka, kuivahtanut kuusi' | ly küzen karaygahaine 'kuivunut kuusi'

Kujk|ozero - sm kuikka | livvi kuikku guikku| ly guik kuikke

Lámb|ovsko - sm lampi | ka lampi lambi ly lamb(i)| ve Lamb|ozero (Ojatin latvoilla MAG 47)

Laht|ozero - sm livvi lahti | ly ve laht

Lёp|ozero - sm leppä | livvi leppy | ly lep(pe) | ve lep

Lobd|ozero - sm ka lauta | livvi laudu | ly laud(e) | ve laud || ksa *lōvdē 'lauta' || Nimeämismotiivina voisi olla laituri.

Lop|ozero - sm Lappi $\mid$ ka lappi $\mid$ ly lap 'pohjoinen maa ja sen asukkaat' tai sm loppi 'takamaa'

Majm|ozero - sm maima 'pikkukala' | ka maima id. | ly maim(e) id. | ve maim id.

Nojdovo oz. - sm ka noita | ly noide | ve noid

Not|ozero - sm ka nuotta | ly nuot(te) | ve not || ksa *nōttē

Pad|ozero - sm pata $\mid$ livvi pada $\mid$ ly pada | ve pada '(savi)ruukku' tai sm, ka pato $\|$ ve pado 'pato'

Sár|lahta - sm saari, sara | ka soari, šara | ly suar(i), sara(heiń) | ve saŕ 'saari', šara|hīn 'saraheinä', sara 'haara'

Sar|ozero ${ }^{1}$

Sar|ozero ${ }^{2}$

Sar|ozero ${ }^{3}$

Hén|ezero - sm heinä | livvi heiny | ly heiń(e) | ve hein, hīn || Mahdollisesti ven. adaptaation kautta diftongi $-e i->e$

Himi|gorsko oz. - sm ka heimo | ve heim, hìm tai luultavammin ims. hlönimi Hima 'haluttu'

Šaim|ozero - ve šaim 'suo, jossa kasvaa harvaa metsää' (Zajceva - Mullonen 1972: 542)

Véni|ručej Venja|ručej ims. vene(h) tai luultavammin sm venäjä | ka veneäh; kaE veńa |ly ve veńa

Gam|ručej - ? ims hämä- 'synkkä, pimeä, utuinen'

Kareng|skoj ručej - sm karanko, karanka 'pystyyn kuivunut nuori puu, kuivunut oksa, riuku, seiväs' | ka karankokuusi 'pitkä ja hoikka, kuivahtanut kuusi' | ly kūzen karaygahaine 'kuivunut kuusi' 
Katick|oj ručej - ve topon. Katitšk $\mid \ddot{a ̈ r}\left(\mathrm{SSA}_{1}\right.$ s. v. katiska $) \sim$ ve vanh. *katitšk(a) + ve oja

Kena - ? < *kennä; vrt. livvi kennäs 'kumpare, töyry'; Kenan rannat ovat paikoin korkeita ja jyrkkiä.

Kindeša - sm 'olla kintaalla' so. reunalla; vrt. Suomen Kintaus (Petäjävesi), Syvärin Kindas (MAG 3) ja Kindus (MAG 102)

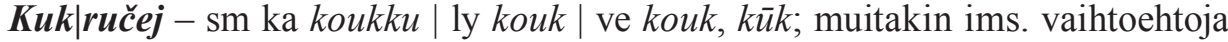
on: sm kukko | ve kukoi, kukei, kukiil, kuk; myös saamelainen vaihtoehto on varteenotettava < ksa *kukkē 'pitkä'; Mullonen (Mullonen - Zaharova 2013: 158) mainitsee, että kohdassa, jossa oja laskee lahteen, sijaitsee korkea mäki, joka on hyvinkin saattanut olla nimeämisperusteena. Tällöin taustalla olisi vepsässä esiintyvä sana $k u k-~$ kukkaz 'mäki' (Zajceva - Mullonen 1972: 242), mikä onkin hyvin mahdollista.

Lёр $\mid$ ručej - sm leppä | livvi leppy | ly lep(pe) | ve lep

Mend|ručej - sm mänty | ka mänty, mändy | ly mänd(ü) | ve mänd

Nojd|ovskoj ručej - sm ka noita | ly noide | ve noid

Órga - sm orko 'kapea laakso' | ka orko 'vesiperäinen, kuusikkoa kasvava notko, rotko' | ly org 'orko, noro' | ve org 'metsää kasvava notko'

Pih|ručej, Pik|ručej < *Pihk|ručej - sm ka pihka| ly pihk(e) | ve pihk'pihka, tiheä havumetsä' | veE pihk 'mänty'

$\boldsymbol{R o v} \mid \boldsymbol{r u c ̌ e j ~ < ~ * R o v d | r u c ̌ e j ~ - ~ s m ~ k a ~ r a u t a ~ | ~ l y ~ r a u d ( e ) ~ | ~ v e ~ r a u d ; ~ o s a ~ r a n n a s t a ~ o n ~}$ nimeltään želéznij voróta 'rautaveräjä'

Saamelaisperäisiä hydronyymejä:

Sollozero; Bol'šó \& Malo - ksa *sōloj 'saari' tai ims suoli

Čung|ozero - ksa *cōykē 'poimia' 〜 sm sonka (Lehtiranta 2001: 26) > saP čoaggit 'poimia, kerätä, koota'; vrt. Sonkajärvi; semanttinen merkitys voisi liittyä kalojen "keräämiseen" verkosta tahi muusta vastaavasta pyydyksestä tai vesien kokoontumiseen monista eri suunnista järveen (tällaisia ovat Suomen Sonkajärvet Ylä-Savossa ja Rovaniemellä).

Čólma Čëlma - ksa *ćōlmē 'salmi'; kapea salmi Kenozerossa

$\boldsymbol{K} \boldsymbol{u k} \mid \boldsymbol{r u c ̌ e j}$ - ksa *kukkē 'pitkä'; voi olla myös ims. perua (ks. edellä)

Lupal|ovo oz. - ksa *lōmpẹl > luompel 'lampi, jonka läpi virtaa joki'

Tóp|ručej - ksa *tōpō 'siepata' > saI tuoppâđđ 'lappaa' esim. köyttä veneeseen, on saattanut liittyä myös kalastamiseen (? 'lappaa siimaa, verkkoa'); vrt. Tuoppajärvi Vienan Karjalassa, Suomessa Tuoppala-nimiset talot Pellossa ja Kiteellä, Tuopanjoki, -järvi Juuassa, Tuopunjoki Pieksämäellä (NA). Nämä voisivat viitata myös henkilönimeen Tuoppa.

Ylävolgalaista nimistöä:

Šuj|ezero; Bol'só, Šuj|ka, Šuj|lahta - merja *śuj 'pitkä, kapea lahti'

Poržen'|sko; Málo - Merjalaisalueella vastineita Kostroman alueen Porž|nja (AKO 177A1) ja mahdollisesti Porz|nja (GBO 222) sekä Porz|inskoj (GBO 227). Myös 
formantti -la on hyvin yleinen merjalaisnimistössä. Määriteosan *porž(V) merkitys on tuntematon, mahdollisesti merjassa on esiintynyt sana porź '(metsä)sika' (ks. edellä). Edellä on esitetty myös Mullosen varteenotettava ehdotus johtaa nimi kantasaamen sanasta *poršōt 'kuohua'.

Poč|ozero, Poča - Merjalaisalueella vastaavuuksia Kljaz'man vesistöalueella Poče|boš (GBO 206), Poč|ega (GBO 215), Vologda-joen sivujoki Počenga (AVO 76B2). Sanan merkitys saattaa olla *poč(V) 'latva'; vrt. mari poč 'häntä, (loppu)pää' (SMJ s. v. noч). Poča-joki laskee Svinoë ozeroon, mikä on antanut aihetta arvella joen nimen liittyvän karjalan sanaan pottši 'sika', mutta mm. Matveev (2004: 164) on aiheellisestikin katsonut sen mahdollisesti olevan kansanetymologiaa. Saarikivi (henkilökohtainen informaatio; 2006b: 56) on katsonut, että huomiotta ei voi jättää alkuperää, joka palautuu kantauralin sanaan *puca, josta *puča-(s) 'pudas'. Tämä onkin mahdollista koska Onega-joen vesistöalueella esiintyy sekä murresana poča (erilaisin variaatioin) että nimien perusosa - poča, jotka molemmat tarkoittavat lahtea tai vanhaa joenuomaa (Matveev 2001: 222). Mullonen (2013: 153) on johtanut nimen saamen sanasta, jonka kantasaamelainen asu on *pōššō sm pohja (Lehtiranta 2001: 106); ks. keskustelu aiheesta edellä.

\section{Venäjän Pohjolan opaakkia nimistöä:}

Važ|ozero - < ? sm.perm.*voša 'haara'; vepsässä esiintyy sana važu 'seiväs, johon vene tai verkko voitiin kiinnittää'. Mahdollisesti taustalla on (para)saamen *vaćo (Mullonen 2002: 288-290).

$\boldsymbol{P a} \mid \boldsymbol{o z e r o}$ - Opaakki nimi, jolla on vastineita mm. Kostroman alueella Pa|ozer (AKO 93A3), Ala-Suhonalla Pa|ozer|ka (AVO 24B2), Ylä-Syvärillä Pa|ozero (MAG 19). Mm. Makarova (2012) ei ole löytänyt sille selitystä. Yksi vaihtoehto nimen alkuperäksi voisi olla *Pa(j)- 'paju'.

Čaženga - Vastaava nimi Čažen'ga esiinty myös Onega-joella sijaiten sen suurimman sivujoen Mošan vesistössä. Eräs ehkä hieman kaukaa haettu mahdollisuus voisi olla johtaa nimikanta mahdollisesta parasaamen sanasta *ćāǔ(V) 'vesi' ksa *ćācē < sgr *śäcä '(tulva)vesi', jolloin jälkimmäinen affrikaatta *c > ̌̌ olisi epäsäännöllinen; vrt. Ojatin latvoilla Čač|ozero, -ručej (MAG 50). Eräs nimen variantti on kuitenkin Čarženga, jolloin *čar- voi liittyä soihin; vrt. Vože-järven eteläpuolella valtava suoalue Čaronda (AVO 35B5) ja Ojatin latvoilla Čar|boloto, Čar|oja, Čar|järv (MAG 55). Mordvassa on sana ćar, jonka yksi merkitys on 'tyhjä, autio' (MWB s. v. ćar); vrt. ven чистий 'puhdas, tyhjä' > чисть 'aava suo'. Makarova (2012: 593) on etsinyt saamelaisia vastineita, jotka ovat melko epäuskottavia.

Tambica, Tamica - Derjagin, Derjagina ja Manihin (1987: 40) esittävät vaihtoehdoksi ims tammi(puu). Tammen kasvuraja on kuitenkin kaukana etelässä täältä. Matveev (2004: 165) esittää eräänä mahdollisuutena tammi 'pato' < skand. damm. Se ei kuitenkaan selitä - $b$ - äännettä. Ehdottaisin, että taustalla on parasaamelainen *temp $(\mathrm{V}) \sim \mathrm{ksa} *$ tempel $\sim \mathrm{saP}$ dappal 'koskien välinen suvanto'. Parasaamelaisella alueella näyttää, että - $l$-johdin ei aina esiinny kantasaamen tapaan, kuten esim. sanassa *luompel 'lompolo'. Vastaava sana esiintyy nimittäin esim. Äänisen seudun nimistössä asuissa Lumba|s ja Lumbu|š (TKRK 77, 86). 
Kumbas oz., Kumbasa - Matveev (2004: 162) on tulkinnut nimen saamelaisperäiseksi < ksa *kumppā 'susi'. Nimeämisperusteena 'susi' on kuitenkin harvinainen vesien nimissä. Suomen pohjoissaamen puhuma-alueilla (Enontekiö, Utsjoki) se esiintyy vain Utsjoella Gumpegohpi (syvänne) ja Gumppeája (puro) (NA). Lisäksi geminaatta - $p p$ - oletettavasti tuottaisi venäläisen adaptaation mukaan *-pp- > $p$. Olettaisin nimen liittyvän samaan nimipesyeeseen kuin Syvärin vesistöalueen hydronyymit Kumbita Kumbiča (Ala-Ojatti MAG 104) ja Kum|ozero Kumuź|ozero (Ylä-Ojatti MAG 44) sekä Äänisentakaisessa Karjalassa Kumbuksa (TKRK 77) ja Kums|ručej (TKRK 55). Katsoisin taustalla olevan sanan, joka palautuu sanaan sm.perm. *kompa (Sammallahti 1988: 537) > kperm *güb 'suo', mdE kumba 'mätäs suossa' (MWB s. v. kumbo), sm kumpu. Ainakin Karjalan ja Kenozeron Kum(b)-nimiset vedet sijaitsevat soiden keskellä.

Soihin voidaan liittää myös Suomessa lähinnä Savossa ja Kainuussa sijaitsevat Kumpunen-nimiset järvet (Mäntyharju, Lapinlahti, Paltamo, Äänekoski, Iisalmi, Rautavaara, Pielavesi, Siilinjärvi, Suonenjoki, Kuopio, Hyrynsalmi). Nämä samoin kuin monet Kumpulampi-nimiset lammet ovat suojärviä/lampia (Kansalaisen karttapaikka). $\mathrm{SMS}_{8}$ esittelee sanat s. v. kumpeikko 'mättäikkö' ja s. v. kumpuilla mm. 'pursuta, kuohua' ja $\mathrm{SSA}_{1}$ s. v. kumpu mm. 'sammalta kasvava korpimaa'. Nämä kaikki voidaan jollain tavoin liittää soihin. Joka tapauksessa moniin niistä on vaikea topografisista syistä liittää suomen sanaa kumpu 'maankohouma'.

\subsubsection{Vertailua Matveevin tutkimustuloksiin}

Koska A. K. Matveev on myös kirjoittanut Kenozeron nimistöstä melko laajasti (2004: 157-165), on syytä arvioida ja vertailla töittemme lopputuloksia. Ensiksi on todettava, että Matveev on käsitellyt muitakin kuin vesien nimiä. Erittäin tärkeä havainto on nimien perusosina esiintyvän maastotermin -šelga, -selga, jopa -čelga 'maan kohouma, selänne' esiintyminen Kenozeron alueella. Tätä voi pitää selkeänä karjalaismarkkerina (Kuzmin 2007: 269); vrt. ka selkä, šelgä, livvi selgy, ly šelg 'selänne, maan kohouma'. Variantti -čelga on äänteellisesti mielenkiintoinen. Matveev (2004: 159) pitää sen kehityskulkua epäselvänä. Yksi vaihtoehto on, että kyseessä on saamelainen käännösadaptaatio itämerensuomalaisesta originaalista selgä $>$ ksa *céelkē 'selkä'. Tällöin olisi oletettava, että varhaisessa Kenozeron itämerensuomessa sana äännettiin vielä vanhakantaisesti *śelgä < länsiural. *śelkä 'selkä' (ks. myös Saarikivi 2004: 216), jolloin venäläinen adaptaatio tuotti horjuvasti erilaisia variantteja $s-, \check{s}-$, c. Näin näyttää tapahtuneen esimerkiksi Okan muromalaisalueella, missä esiintyy sellaisia variantteja kuin Konśera $\sim$ Konš́ura $\sim$ Konšjura $\sim$ Končura (GBO 198) ja Konšur Končur (GBO 231) ? < *konśər. Tässä yhteydessä on syytä verrata kyseistä sanaa myös äänteellisesti vastaavaan Pohjois-Venäjällä esiintyvään murresanaan čil'ma 'suo, suonsilmä' < *śilmä (lähteen); ks. Saarikivi 2004: 199; Dal', 1882 s. v. чильма.

On kuitenkin tapauksia, joissa itämerensuomalaiset nimet muistuttavat enemmän vepsää kuin karjalaa. Ellei Not|ozeroa tulkitse saamelaiseksi < ksa *nōttē (Lehtiranta 2001: 84), se lienee kuitenkin johdettavissa vepsän sanasta not 'nuotta'. 
Toisaalta Kargopolin seudun samaten diftongistumaton nimi Hosi $\mid$ ma $<$ *hoosia 'huosia(korte)' voi viitata jo varsinaista vepsäläisaikaa varhaisempaan itämerensuomeen, koska sibilantti vepsästä poiketen on säilynyt soinnillistumattomana. Myös toinen kalastusväline voisi olla vepsäläisperäinen; vrt. Katick|oe ručej, jolla on vastine vepsäläisnimistössä Kat’ičk| är < kadonnut vepsän sana *kat’itšk 'katiska'. Etenkin vepsässäkin harvinainen murresana šaim 'suo' (Zajceva - Mullonen 1972: 542) > Šaim|ozero näyttää selvästi vepsäläisperäiseltä, vaikkakin se epäilemättä palautuu johonkin substraattikieleen ennen vepsäläisaikaa esiintyen myös venäjän murresanastossa; ks. Makarova 2012: 602-603. Vastaava suon nimi Šaim Šajmenskoe bolota esiintyy myös Ojatin latvoilla (MAG 42).

Joissain tapauksissa Matveev on tulkinnut o:lliset Lobd- ja Rovd-nimet saamelaisiksi; vrt. ksa *lōvtē 'lauta' ja *rōvtē rauta. Yhtä hyvin tai ehkä mieluumminkin kyseiset nimet ovat pohjoisvenäläisestä vaikutuksesta $o$ :llistuneet ims. *a:sta; *raud(a) $>$ ровд- ja *laud(a) > ловд-. Mullonen (2002: 48 ja siihen liittyvä kirjallisuus) on esitellyt nimiesimerkein vanhoja venäläisiä adaptaatiota, joissa ims. *a $>$ ven $o$.

Joka tapauksessa olemme Matveevin kanssa tulleet pääasiasta samaan lopputulokseen. Saamelaisperäisiä nimiä löytyy, mutta niiden määrä on suhteellisen vähäinen verrattuna itämerensuomalaiseen. Jos tarkastelemme Saarikiven (2004) esittämiä (para-)saamelaisia substraattinimiä esittäviä karttoja (4-18), huomaamme, että Kargopolin-Kenozeron alueella niitä esiintyy suhteellisen vähän. Kenozeron seutu on ollut vahvasti itämerensuomalainen saaden myöhäisempiä vaikutteita niin karjalasta kuin vepsästäkin. Kuitenkin seudun alkuperäinen (?) viikinkiaikainen (tai jopa sitä varhaisempi) itämerensuomi on ilmeisesti ollut sen omaperäinen itäinen murre. Kielen säilymisestä ehkä 1700-luvulle asti antaa vihjeen vanhemmalle venäjän kielelle lähes mahdottoman - $h k$-konsonanttiyhtymän säilyminen nimistössä: Vahk|ozero ja Pihk|ozero (ks. Mullonen 2002: 64). Läheisellä Vodlan alueella on säilynyt bylina Ragnjärven Rahkoi-nimisestä muinaissankarista (ks. jäljempänä luku 6). ${ }^{13}$ Bylinasta on lukuisia versioita, joiden ikää voi seurata sen mukaan, mihin tsaarin hallitusistuin on sijoitettu. Vanhimmat sijoittavat sen Kieviin, nuoremmat Moskovaan ja kaikkein nuorimmat Pietariin. Myös nimi Rahkoi muuttuu bylinoissa venäläistymisasteen edetessä: *Rahkoi $>$ Rahta $>\operatorname{Rak}(k a) \sim$ Rag. Ensin mainittu esiintyy oletettavimmin siellä, missä kieli säilyi kauimmin. Rahta on suhteellisen vanha substituutiomalli ja Rak/Rag sitä myöhempi. Useimmat Venäjän Pohjolan Rahkola-nimiset kylät ovatkin muuttuneet asuun Rakol- tai Rakul- (ks. edellä kartta 6). Vastaavasti Kenozerolla virtaavan Pihk|ozeroon liittyvän puron nimellä on variantit Pik|ručej $\sim$ Pih|ručej. Itämerensuomalainen - $h k$ - voi siis substituoitua $-h t$ :na, $-v k$ :na tai vain $k$ :na tai $g$ :nä, jopa $h$ :na (ks. myös Saarikivi 2006: 23).

Ylävolgalaisena pidettävää tai opaakkia paikallisempaa nimistöä esiintyy melko vähän verrattuna Kargopolin alueen nimistöön. Tämäkin antaa viitteitä itämerensuomalais-saamelaisen asutuksen hamaan menneisyyteen ulottuvista pitkistä juurista. Suurin osa alkuperältään muusta nimistöstä on ilmeisesti peittynyt näiden alle.

13. Bylina on venäjän kielessä esiintyvä termi, jolla tarkoitetaan hyvin vanhaa kansan muistitietona periytynyttä tarinaa. 


\subsubsection{Vertailua Helimskin tutkimustuloksiin}

On syytä myös verrata edellä esitettyjä johtopäätöksiä Helimskin (2006: 109-127) hypoteesiin luoteisesta suomalais-ugrilaisesta kantakielestä (Northwestern Group of Finno-Ugric Languages). Hän perustelee hypoteesiaan juuri Kenozeron, Kargopolin ja Belozeron alueiden vesistönimistöllä. Heti alkuun on todettava, että Helimskin ajatus laajasta luoteisesta suomalais-ugrilaisesta kantakielestä tulee joiltain osin lähelle omaa esitystäni länsiuralilaisesta kantakielestä (Rahkonen 2013b: 242-243). Hän on tosin aiheetta sulkenut pois mordvan ja hän ei huomioinut novgorodilaisten itä- ja länsitšuudien jälkeensä jättämää nimistöä Novgorodin ja Tverin alueilla (ks. Rahkonen 2011).

Helimski käsittelee alueen suurten vesien nimiä: Und-, Ond-, And-nimet, Lača, Vože, Poča, Vaga ja Kena/Kenozero. Lisäksi hän tarkastelee -nga/-n'ga-formanttia. On suoraan sanottava, ettei yksikään hänen etymologisista ratkaisuistaan ole vahvalla pohjalla. Hän vertaa $(V) n d$-nimiä suomen sanaan vuo $<$ sgr. *uwå (Sammallahti 1988: 542) arvellen siihen liittyvän johtimen -nto, siis *uwånto > And-, Ond-, Und-. Nimien alkuvokaalien $u$-, $o$ - ja jopa $a$ - johtaminen kantasanasta *uwå vaatii suurta mielikuvitusta. Suuren järven nimen Lača hän katsoo palautuvan samaan originaaliin kuin suomen laho. Suomessa määriteosa laho- esiintyy harvoin ja silloinkin vain joidenkin hyvin pienten vesien yhteydessä: Laholampi, Laholuoma. Suurten vesien yhteydessä se ei esiinny koskaan. Toisen suuren järvennimen Vože hän katsoo olevan verrattavissa suomen sanaan ohi, verraten sitä Suomessa esiintyviin Ohe-, Ohennimiin. Kyseiset suomalaisnimet kuitenkin palautuvat vaihtoehtoisesti sanoihin *ohti : ohen tai *oksi : ohen. ${ }^{14}$ Helimski katsoo, että nimi Poča palautuu samaan originaaliin kuin suomen pohja ja kantasaamen *pōššō. Hän toteaa itsekin, että konsonanttiyhtymien - $h j$ - ja - ̌̌š - taustalla olevan kantasanan määrittäminen on vaikeaa. Hän päätyy sellaiseen asuun kuin * počja, vaikka toteaakin, ettei vastaavaa konsonanttiyhtymää *-čj- ole löydetty itämerensuomesta eikä saamesta. Näin ollen kyseinen rekonstruktio on varsin heikolla pohjalla, vaikka myöntäisikin sen teoriassa olevat mahdollinen. Nimi Vaga on useinkin Helimskin tavoin selitetty juontuvan itämerensuomen sanasta vaka(a). Uskallan epäillä tätäkin, koska nimeämisperuste olisi sangen harvinainen. Suomessa ei esiinny yhtäkään hydronyymiä, jonka määriteosa olisi vaka-. Luulisin nimen olevan niin vanha, että se palautuu johonkin paleo-eurooppalaiseen tuntemattomaan kieleen niin kuin myös nimi Viena $\sim$ Dvina $<*$ Vēna. Kenozero ja Kena-joki ovat Helimskin mukaan johdettavissa itämerensuomen sanasta keno johtuen järven muodosta. Suomessa ei esiinny yhtäkään keno-järveä tai -jokea. Olen esittänyt, että taustalla olisi karjalan sana kennä-s 'töyry'. Suomessa esiintyy joitain vastaavia nimiä, kuten Kenninoja, Kennioja, Kennäänlahti (NA), joten nimeämisperuste on joka tapauksessa tuttu. Voi olla niinkin, että nimi on alun perin ollut *Kemi-.

Helimski päätyy joidenkin muiden tavoin (ks. Helimski 2006: 114 ja siihen liittyvä kirjallisuus) selittämään formantin -nga, -n'ga nimen määriteosan genetiivin $n$ :stä ja jokea merkitsevästä sanasta juga samaan tapaan kuin suomalaisnimistössä yleinen malli xxxx:njoki; so. *xxxx-njuga > -n(')ga. Matveev (2001: 261-275) on

14. Kaikki Ohe(n)-paikannimet Suomessa sijoittuvat savolaismurteiden alueelle (Kansalaisen karttapaikka). 
esitellyt laajasti ja syvällisesti kyseisen formantin erilaisia selitysmalleja ja suhtautuu kriittisesti, jopa skeptisesti edellä esitettyyn selitykseen. Matveev katsoo, että on kiinnitettävä vakavaa huomiota - $n($ ')ga-hydronyymien mahdolliseen yhteyteen suomalaisten -nki-nimien kanssa" (Matveev 2001: 264). Tähän näkemykseen on helppo yhtyä. Aiheen laajuuden tähden tässä artikkelissa ei voi syvemmin käsitellä tätä asiaa.

\section{Kargopolin-Kenozeron kansanperinne}

\section{I. Kenozeron historian kansatieteellinen näkökulma}

Sen lisäksi, että Kenozeron alue on vanhojen, jo muualta slaavilaisesta maailmasta kadonneiden bylinoiden maa (Gunn 1984: 70-72), siellä heijastuu tänä päivänäkin suomensukuisten heimojen pakanuudenaikainen menneisyys. Yhä uudelleen kirjallisuudessa ja matkakertomuksissa puhutaan "legendaarisista tšuudeista", vaikkakin venäläinen kirjallisuus keskittyy alueen kieltämättä mestarillisiin kirkollisiin rakennuksiin (Višnevskaja - Gorohov 1997; Fedorov 1978; Gunn 1984).

Kenozeron kansallispuiston alueella on laskettu säilyneen 29 pyhää lehtoa, joiden historian katsotaan palautuvan muinaissuomalaiseen pakanuuden aikaan (Višnevskaja - Gorohov 1997: 392). ${ }^{15}$ Tämän lisäksi on pyhiä yksittäisiä puita ja lähteitä. Tunnetuin lehto sijaitsee Veršininon $\sim$ Kenozeron kylässä tsasounan kupeessa ja toinen suosittu lehto sijaitsee Šiškinon kylässä. Veršininossa viereisen järven rannassa ei esimerkiksi ole lupa kalastaa. Nuorisolla on ollut tapana kuljeskella kesäöisin näissä lehdoissa (Gunn 1984: 102, 111). Ortodoksinen kirkko on tietenkin rakentanut lehtoihin kirkkoja ja tsasounia korvatakseen aiemman pakanallisen uhritoiminnan ja muut pakanalliset tavat, mutta kansa on silti suuresti kunnioittanut lehtoja ja lähteitä aina näihin päiviin asti (mp.).

Gunn (1984: 81) mainitsee kuulemastaan entisestä erikoisesta tavasta juhlistaa Ivanovin päivää (juhannusta) siten, että kaikissa kylissä kokoonnuttiin korkeille rantatöyräille polttamaan kokkoa. Tämä tapahan on suomalaisille tuttu. Epäilemättä se perimmiltään palautuu pakanalliseen Ukon palvontaan. Vielä 1800-luvun lopulla Etelä-Karjalassa heitettiin erilaisista langoista neulottu ja eri viljalajien siemeniä sisältävä pussi "kokkovaltiaalle" kylän vanhimman sytyttämään juhannuskokkoon. Johannes Häyhä kertoo, että hänen isoisänsä aikana vielä luettiin tässä yhteydessä pitkä loitsu, johon kuuluivat mm. sanat: "Oi Ukko ylinen luoja, taatto taivahan jumala... nosta korret korttumahan, sekä varret varttumahan” (Häyhä 1898: 35, 38). Juhannuskokon polttaminen ei ole ollut tapana venäläisten tai vepsäläisten keskuudessa eikä sitä Karjalassakaan esiintynyt ilmeisesti kuin ns. Suomen Etelä-Karjalassa. ${ }^{16}$

15. Suomen sanaa lehto ei tässä yhteydessä tule tulkita kirjaimellisesti vain lehtipuuta kasvavaksi metsiköksi. Venäjässä käytetään tässä yhteydessä sanaa poщ̧a, mikä yleensä käännetään suomen sanalla 'lehto'. Kyseessä oli useinkin sekametsää kasvava alue, mikä ymmärrettiin pyhäksi, tavallisesta erotetuksi metsiköksi ja missä voitiin päästä kosketuksiin yliluonnollisten voimien kanssa. Sitä varten jumaluuksille yleensä tuotiin jotain lahjaksi. Siellä ja jopa lähistöllä oltaessa oli myös käyttäydyttävä asiaankuuluvalla kunnioituksella ja hartaudella.

16. Ainakaan minun haastattelemani Petroskoin kansatieteilijät eivät tienneet, että Karjalan tasavallan alueella olisi noudatettu kyseistä tapaa. Vepsäläiset polttivat kyllä kokkoa Pedrun päivänä, mutta eivät juhannuksena. 
Kannaksella oli tapana polttaa juhannuskokkoja rannansuuntaisesti rivissä yhden kokon ollessa muita suurempi ns. "Ukko-kokko". ${ }^{17}$ Kokon polttamisen tapa on kaikkien lähteiden mukaan alkuaan itä- ja pohjoissuomalainen. Tavan levintä verrattuna Suomen yleiseen asutushistoriaan viittaa siihen, että juuri Karjalankannas ja eteläinen Saimaan vesistöalue on sen lähtöalue. Olettaisin, että Kenozerolla kyseinen tapa on peräisin jo alueen viikinkiaikaisilta itämerensuomalaisilta asukkailta, joilla saattoi olla paljonkin yhteisiä perinteitä Karjalankannaksen suomalaisten kanssa. Luulisin tavan siirtyneen itämerensuomalaisille skandinaaveilta, vaikkakin perinne esim. Ruotsissa on sammunut jo 1800-luvulla.

Kargopolin piirin puolella lähellä Lëkšm|ozeroa on rakennettu erilleen asutuksesta alueen korkeimmalle mäelle suurehko kirkko. Gunn (1984: 59-60) on arvellut rakentamisen juuri tuollaiseen paikkaan johtuneen slaavilaisesta mielenmaailmasta, joka suorastaan vaati kirkon rakentamista maiseman kauneuden tähden kyseiselle mäelle. Nimistöntutkijalle syy on kuitenkin selvä. Mäen nimi on nimittäin Hiž|gora, 'Hiisimäki'. Paikka on epäilemättä ollut keskeinen itämerensuomalaisen väestön aikainen pakanallinen palvontapaikka, jollaisiin ortodoksinen kirkko säännönmukaisesti rakensi kirkon tai tsasounan.

\subsection{Haastattelututkimuksen tuloksia}

Suoritin ryhmäni kanssa kenttätutkimusta Kenozeron seudulla haastattelukaavakkeen avulla. Tiedustelin olivatko nykyiset asukkaat kuulleet vanhojen puhuvan kansasta nimeltä tšuudi, ihmisistä, joita kutsuttiin valkosilmäisiksi tai jotka olisivat kadonneet hautaamalla itsensä maan alle. ${ }^{18}$ Edelleen kysyttiin, ovatko he koskaan kuulleet mytologiaan liittyviä sanoja $u k k o$, rahkoi $\sim$ rahta, ilma tai ilmaŕ, vihtoi $\sim$ vihtui, noid(a), hiz tai perun. Kysyttiin myös, olivatko he kuulleet vanhojen mainitsevan ennen alueella asuneista kansoista kuten karel, lopaŕ, veś $\sim$ veps, komi $\sim$ zyrjan, gam $\sim$ jam $\sim$ jem. Lisäksi kysyttiin, oliko kuultu Kenozerolla ennen eläneistä ei-venäläisistä, jättiläisistä tai erityisen ilkeistä ihmisistä. Informanteilta kysyttiin myös tietoa pyhistä lähteistä, uhrilehdoista tai yksittäisistä pyhiksi katsotuista puista.

Zavoloč'esta kotoisin oleva ikämies muisti kuullensa taannoin tapahtuneesta kanssakäymisestä puolin ja toisin karjalaisten kanssa. Sama informantti tiesi kertoa pyhästä lehdosta Zavoloč'essa tsasounan vieressä. Hänellä oli myös tieto, jonka mukaan siellä oli suuri kivi nimeltä pljasušij kamen' (tanssikivi) tai toiselta nimeltä vesëlij kamen' (ilokivi). Etsimättä nousee mieleen Väinämöinen soittamassa ilokivellä. Kyseessä on varmaan juuri nuorison tapa kokoontua kesäöinä pyhiin lehtoihin (ks. edellä) karkeloimaan, kuulemaan soittoa ja laulamaan. Myöhemmin joku "hyvin uskonnollinen" ihminen oli pystyttänyt sinne ristin.

17. Katso suomalaisesta kokkoperinteestä Karjalainen, Sirpa 1994: Juhlan aika: Suomalaisia vuotuisperinteitä. Porvoo Helsinki Juva: WSOY, Teppo Korhonen 1979: Juhannus. Juhlakirja. Kalevalaseuran vuosikirja 59. Helsinki: Suomalaisen Kirjallisuuden Seura ja linkki <http://www.tunturisusi. com/juhannus/kokko.html>. - Etsiessäni tietoa juhannuskokon polttamisen tavasta Suomessa havaitsin, että aiheesta on loppujen lopuksi kirjoitettu todella niukasti. Edellä esitetty linkki oli yllättäen kattavin esitys, joten huolimatta sen kyseenalaisuudesta tieteellisenä lähteenä, on siihen viitattu.

18. Tämä tšuudeihin liittyvä legenda on laajalle levinnyt Pohjois-Venäjällä (mm. Saarikivi 2006: 11). 
Toinen vanhempi samoin Zavoloč'esta kotoisin oleva mies kertoi ennen alueella asuneista kansoista. Hän sanoi kuulleensa, että muinoin Kenozeron alueella asui kansoja nimeltä lopaŕ 'lappalainen' ja skobaŕ 'pskovskilainen' eli novgorodilainen. Nimistökin todistaa saamelaisten asuneen täällä. Maininta skobareista voi palautua keskiajalle, jolloin seutu kuului Novgorodin vallan alle. Toisaalta voisi myös ajatella, että näin puhuessaan paikalliset eivät ennen aikaan olleet katsoneet olleensa novgorodilaisia - siis venäläisiä - vaan itämerensuomalaisia. Tähän voisi viitata sekin, että kukaan ei muistanut, että alueella olisi asunut muinoin tšuudeja tai karjalaisia, vaikka vesistönimistössä on runsaasti itämerensuomalaisia hydronyymejä. Näin ollen olisi ollut tarpeetonta muistella omaa kansaansa ennen alueella asuneina asukkaina.

Edellä mainittu informantti oli kuullut myös version Puudoisen alueella tunnetusta tarinasta, joka on liitetty bylinaan kaksintaistelijasta nimeltä Ragnjärven Rahkoi. Ragnozero sijaitsee Vodla-järven länsipuolella. Hänen tuntemansa version mukaan voimamies asui Us'kolodin (virall. Ust' Koloda) kylässä Vodlan alueella. Legenda on kaksiosainen: 1) Rahkoi voittaa varjagin kaksintaistelussa tsaarin luona ja 2) vaimo pettää häntä rosvopäällikön kanssa ja sidotuttaa hänet. Hän saa lapseltaan puukon, vapauttaa itsensä ja tappaa rosvot, jotka olivat juuri kylpemässä saunassa. Tämän informanttini kuulema versio käsitti vain jälkimmäisen osan kertomuksesta eikä hän tuntenut Rahkoi-nimeä. Nimi tunnetaan parhaiten oikeassa muodossaan juuri Ragnozerosta kerätyssä materiaalissa. Kauempana nimi muuttuu vanhavenäläiseen tapaan muotoon Rahta, Rakka, Rag, Rah tai Rak (Čistov 1958: 358-388). Kenozerolla nimi oli kadonnut kokonaan. Ragnozerolla joku informantti tiesi kertoa, että tsaari istui tuolloin Kievissä. Yleensä paikka sijoitettiin Moskovaan ja joskus Pietariin tai jopa Leningradiin. Olettaisin, että tieto tsaarin valtaistuimen sijainnista Kievissä juuri varjagiaikana tuskin on ollut koulutuksen kautta vanhan kansan tiedossa. Kyseessä lienee ikivanha perimätieto.

Eräs Mizasta syntyisin oleva nainen oli kuullut, että joitain ihmisiä oli kutsuttu 'valkeasilmäisiksi' (белоглазыми) tai hyvin mielenkiintoisesti nimellä воло|глазыли, jossa volo- < ims *valko-. Hän muisti kerrotun, että jos joku puhuu heistä, niin joutuu itse haudatuksi maan alle. Myös Mizassa oli joitain tsasounia, joiden luona oli pyhiä lehtoja. Počan ja Kenozeron välisen tien varressa on suuri mänty, jonka kohdalla nykyäänkin pysähdytään mentäessä häihin tai lähdettäessä armeijaan. Itse näin, että kyseiseen mäntyyn oli sidottu paljon värikkäitä kankaan kaistaleita. Erään toisen informantin mukaan kangaskaistojen sitominen on aivan viimeaikainen tapa.

Mininosta syntyisin oleva vanha rouva oli kuullut, että Kuz'minkan ja Terehovin välillä kokonainen talo oli vaipunut maan alle ihmisineen, kun taloon oli saapunut valkohampainen (!) ihminen. Tällä peloteltiin lapsia ja nuoria, että heille voi käydä samoin. Hän tiesi, että Mininossa kirkon luona oli pyhä lehto ja lisäksi kylässä oli 3 lähdettä. Kun hän lapsena sairasti, niin hän parantui, kun hänen äitinsä kävi näillä lähteillä. Rižkovosta kotoisin oleva, mutta myöhemmin Glubokoeen muuttanut vanha nainen tiesi, että myös sekä Rižkovossa että Glubokoessa oli pyhät lehdot.

Eräs vanhempi herrasmies osoittautui erittäin älykkääksi ja hyvämuistiseksi ihmiseksi. Hän oli kotoisin Kumbasozerosta Karjalan tasavallan ja Arkangelin alueen rajalta. Myös hän oli kuullut puhuttavan seudulla ennen asuneista lopareista. 
Hän oli kuullut "alle 100-vuotiaalta" vanhukselta, että hänen omat sukujuurensa ovat "ruotsalaiset" hyvin kaukaisilta ajoilta. Epäilemättä kyseessä oli 1600-luvun Ruotsin valtaamilta ortodoksikarjalaisten alueilta Käkisalmen läänistä muuttanut karjalaissuku. Vielä vuonna 1887 monet vodlajärveläiset muistivat, että erään kylän asutuksen alkuperä on "ruotsalainen" ja toisen tšuudilainen, mutta osa oli venäläisten rosvojen ja pakolaisten jälkeläisiä (Haruzin 1894: 320). Tämä kumbasozerolainen muisti kuulleensa, että myös heidän luonaan asui väkivahvoja sankareita (ven bogatirr). Hän kuuli tapauksesta, jolloin hevonen nääntyi raskaan kuorman alle, mutta neljä miestä veti rattaat ja kuorman Zavoloč'esta Kumbasozeroon saakka. Myös Kumbasozerossa on pyhä lehto kirkon luona.

Kenozerossa erään klubin sisäseinään oli raapustettu slaavien muinaisen pääjumalan Perunin nimi. Ehkä kyseessä oli kuitenkin vain koulussa opitun toistoa. Joka tapauksessa vaikuttaa siltä, että niin slaavilainen (bylinat) kuin itämerensuomalainenkin (uhrilehdot) muinaisuus vielä henkii kyseisellä alueella monin tavoin. Sinänsä mielenkiintoista on, että etnonyymi tšuudi oli täysin tuntematon Kenozerolla niin nimistössä kuin perimätiedossakin. Samaan tilanteeseen törmättiin tutkimuksissa, joita suoritettiin vuoden 1994 jälkeen Karjalan tasavallan puolella Vodlajärven alueella (Loginov 1999: 108). Voi olla, että etnonyymi tšuudi oli syystä tai toisesta (ehkä pakanuuden vuoksi) saanut siksi huonon maineen venäläisten keskuudessa, ettei kukaan halunnut identifioitua sellaiseksi. Toisaalta kuitenkin esimerkiksi Pinegajoella Saarikivi (2006b: 11, alaviite 9) tapasi miehen, joka nimenomaan itse piti itseään tšuudina. Tšuudi-etnonyymistä rakennettuja paikannimiä ei esiinny Kenozerolla, mikä saattaa viitata siihen, ettei sitä käytetty tuolla alueella.

\section{Yhteenvetoa ja keskustelua}

\section{I. Kargopolin ja Kenozeron alueiden erilaisuus}

Silmäänpistävin ero Kargopolin ja Kenozeron välillä on niiden täysin erilaiset nimistölliset yhteydet Ylä-Volgalle. Tämä vahvistaa sitä näkemystä, että vanhavenäläinen hallinnollinen raja Novgorodin (Kenozero) ja Rostov-Suzdalin ruhtinaskunnan (Lačajärvi) välillä merkitsi myös kielellistä rajaa, vaikkakaan ei välttämättä kovin

jyrkkää sellaista. Kargopolin seudulla merjalaistyyppinen nimistö on kuitenkin selkeästi yleisempää, kun taas Kenozerolta se puuttuu lähes kokonaan. Vastaavasti itämerensuomalainen nimistö Kargopolin alueella on paljon heikommin edustettuna kuin Kenozerolla. Voisi ajatella, että Kargopolin seutu slaavilaisen muuttoliikkeen alkuvaiheessa oli "kansainvälisempää". Venäläinen vaikutus oli heti vahvempaa, koska Novgorodin jo v. 1146 perustama Kargopol' oli merkittävä kaupan keskus ollen koko Venäjän Pohjolan ensimmäinen kaupunki. Ortodoksisen kirkon vaikutus Kargopolin alueella oli myös vahva myöhäiseltä keskiajalta lähtien, mikä oli omiaan vahvistamaan venäläistymistä. Kenozeroa sen sijaan voi luonnehtia pitkään aivan itämerensuomalaiseksi seuduksi lisättynä saamelaisella komponentilla. Kaikesta päätellen pakanuudella oli otteensa vielä pitkään senkin jälkeen, kun väestö 
oli nimellisesti kastettu ortodokseiksi, aina lähes näihin päiviin asti. Ainakin järvien nimet näyttävät siellä olevan valtaosaltaan itämerensuomalaista perua. Suuri osa järvien nimistä tosin perustuu venäläisiin antroponyymeihin, mutta venäläisperäisiä henkilönimiähän myös itämerensuomalaiset käyttivät. Osa on ilmiselviä käännösnimiä. Myös Kenozeron kansanperinteen vanhempi kerrostuma vaikuttaa vahvasti itämerensuomalaiselta.

\subsection{Itämerensuomalaisuuden luonne tutkittavalla alueella}

Näyttää siltä, että vanhin itämerensuomalainen asutuskerrostuma on jollain lailla yleissuomalaista. Kaikille yllä esitetyille itämerensuomalaisille substraattisanoille löytyy vastine suomen kielestä, useimmille myös karjalasta. Sen sijaan monia puuttuu vepsästä. Nimistö on monikerroksista. On nimiä, jotka saattavat viitata karjalaiseen alkuperään, kuten Kujk|ozero, sillä sanaa 'kuikka' ei esiinny vepsässä. Myös Kena-joen ja Ken|ozeron nimet saattavat pohjautua karjalassa - mutta ei vepsässä - esiintyvään sanaan kennä-s 'kumpare, töyry' (KKS s. v. kennäs), joka voi viitata Kenan yläjuoksun varsin korkeapiirteisiin rantoihin. Vastapainoksi on sanottava, että Kenozeron hydronyymeissä esiintyy selkeitä ja jopa karjalaisuuksia paremmin todistettavissa olevia vepsäläisyyksiä, kuten esim. Šajm|ozero, Katick|oj|ručej ja Pihk|ozero, jossa pihk(a)-sanaa on todennäköisesti käytetty vepsän tapaan merkityksessä 'tiheä havumetsä'. Myös Not|ozero (vrt. ve not 'nuotta') vaikuttaa vepsäläiseltä.

Kargopolin alueella näyttää historian eri vaiheissa asuneen niin vepsäläisiä kuin karjalaisiakin. Maininnat venäläistyneistä tšuudikylistä 1800-luvun jälkipuoliskolla viitannevat vepsäläisiin, koska sanaa tšuudi käytettiin myöhemmässä venäjässä merkityksessä 'vepsäläinen' (Bubrih 1947: 24). Samoin alueen *Rahkola > Rakol-, Rakul-kylännimet liittynevät vepsäläisiin (ks. kartta 7). Karjalaistakin väestöä on asunut Kargopolin alueella, mistä todisteena ovat kylien nimet Karel'skaja sekä Podkarel'skaja. Keskiaikaisissa lähteissä on maininta karjalaisista (корел) ja tšuudeista kauempana idässä Kubena-järvellä niinkin varhain kuin vuodelta 1251 . Sikäläiset munkit valittivat Valkeajärven ruhtinas Gleb Vasil'evičille paikallisten karjalaisten ja tšuudien taholta tulleista ongelmista (Bubrih 1947: 37). Kertomus vaikuttaa uskottavalta nimistönkin valossa, sillä itämerensuomalainen nimistö on levittäytynyt melko vahvasti Ylä- ja Keski-Suhonan pohjoispuolelle (kartta 3).

\subsection{Venäjän keisarilliset kuvernementit ja ikivanhat heimorajat}

Kun ajattelemme vuoden 1796 jälkeisiä Venäjän kuvernementtien rajoja, tuntuvat ne nykytilanteen valossa vähintäänkin kummallisilta (kartta 8). Jotkut hallintokaupungit sijaitsivat aivan alueensa reunassa (Novgorod, Vologda) tai liikenteellisesti vaikeasti saavutettavissa, kuten Petrozavodsk Kargopolin alueen asukkaille. Miksi Olonetsin kuvernementti käsitti Karjalan, Vepsänmaan ja Äänisjärven taustan lisäksi taipaleentakaiset Onega-joen yläjuoksun valuma-alueet? Miksi Novgorodin kuvernementti ulottui valtavien korpimaiden läpi aina Valkeajärven alueelle asti, jonka olisi luullut luontojaan kuuluvan Vologdan kuvernementin yhteyteen? Miksi vuorostaan 
Vologdan kuvernementti käsitti koko komilaisen maan? Uskon, että taustalla ovat ikivanhat suomalais-ugrilaiset heimorajat. Olonetsin kuvernementti (v:sta 1802) tietysti pohjautui jo Novgorodin tasavallan Äänisen viidennekseen ja sen välittömiin takamaihin taipaleen takana. Mutta se taas perustui selvästikin vanhoihin itämerensuomalaisten heimorajoihin sisältäen Ala-Olhavan itärannan tšuudien, vepsäläisten ja karjalaisten ydinalueet.

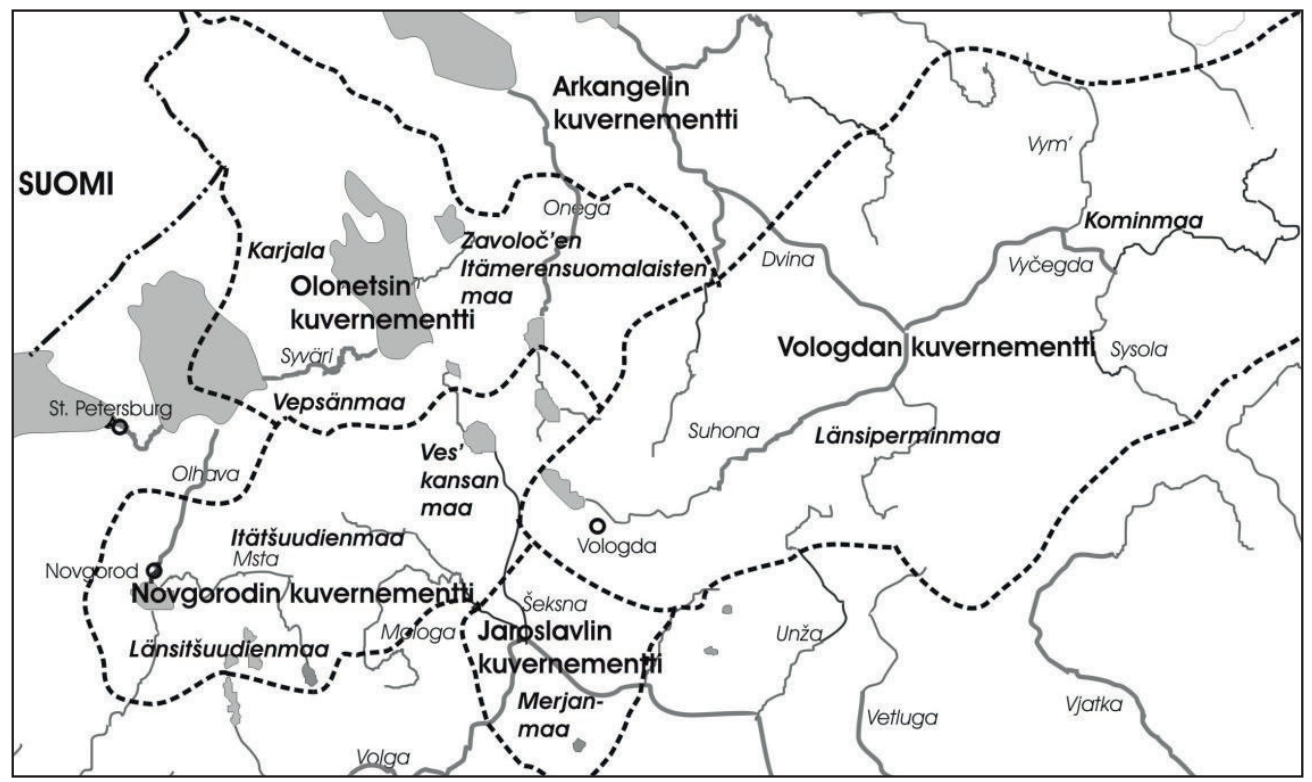

Kartta 8. Keisarillisen Venäjän kuvernementteja (perustettu 1796-1802). Kaavamainen kartta.

Tietenkin hallintokaupungit Novgorod, Jaroslavl, Petrozavodsk ja Vologda olivat varhaisesta asti merkittävissä määrin venäläisiä ja siksi venäläisille hallituksille tärkeitä. Tästä syystä oli selvää, että hallinto keskittyi niihin. Joka tapauksessa koko Olonetsin (Aunuksen) kuvernementti saatettiin perustaa ikivanhastaan itämerensuomalaiseksi mielletylle maaperälle, vaikkakaan tätä eivät kuvernementin rajojen vetäjät tietenkään aktiivisesti ajatelleet. Itämerensuomalaisia kieliä oli oletettavasti paikoitellen puhuttu tuolla alueella kaikilla kuvernementin seutukunnilla vielä 1700-luvulla (ks. edellä). Olonetsin kuvernementtiin kului 7 kihlakuntaa: Aunuksen, Petroskoin, Poventsan, Puudoisen, Vytegran, Lotinanpellon ja Kargopolin. Vastaavasti Vologdan kuvernementti (v:sta 1796) käsitti pääasiassa Kominmaan lisäksi vanhoja länsipermiläisiä maita (Bubrih 1947: 30; Rahkonen 2014: 336, map 1 ja 366, map 2). Suhonan keski- ja alajuoksulla puhuttiin permiläistä kieltä ainakin vielä keskiajan lopulla. Jaroslavlin kuvernementti (v:sta 1796) sijoittui muinaisille merjalaisten maille. Joidenkin tutkijoiden mielestä merjaa puhuttiin paikoitellen vielä jopa 1700-luvulla (Tkačenko 2007: 307). Novgorodin kuvernementti (v:sta 1796) vuorostaan koostui pääosin keskiajan novgorodilaisten tšuudien alueista kattaen itse Novgorodin ympäristön lisäksi pääosin muinaisten Bežeckin (itätšuudit) ja Derevan (länsitšuudit) viidennesten maat 
(Rahkonen 2011: 242, map 8). ${ }^{19}$ Keisarilliset kuvernementit lakkautettiin 1920-luvulla Neuvostoliiton alueellisen uudelleenorganisoimisen seurauksena.

\subsection{Parasaamelainen nimistö}

Parasaamelainen nimistökerrostuma on varma tosiasia ns. "järvienvälisellä alueella". Kargopolin alueella se kuitenkin on harvalukuista. Saamelaisnimistö keskittyy ensisijaisesti Valkeajärven ja Ojatin väliselle alueelle sekä Vože-järven ympäristöön (ks. kartta 3). Mielestäni Manjuhinin (2005) idea yhdistää myöhäiskargopolin kulttuuri saamelaisen etnoksen syntyyn on yliampuva. Tosiasia on, että Valkeajärven ympäristö on nimistön perusteella ollut varsinainen "Baabelin kielten sekoitus". Siellä kohtasivat merjalaiset ja joku sen sukukieli, saamelaiset ja kieli, jossa esiintyi sana * $\beta$ oj(V) 'joki' (ks. edellä). Viimeksi mainittuun liittyvät nimikannat eivät ole johdettavissa saamesta tai merjasta. Näin ollen $\beta o j$-perusosaa ei voi liittää parasaameen. Myöhemmin joukkoon liittyi myös itämerensuomalainen nimistö. Lisäksi esiintyy nimistöä, joka saattaa olla jotain paleo-eurooppalaista kieltä sekä Rahkosen (2013) olettamasta länsiuralilaisesta $x$-kielestä kumpuavat hydronyymit. Tämä nimistön monimuotoisuus ei ole mikään ihme, sillä seutu on etelästä (Šeksna, Andoga), idästä (Suhona), pohjoisesta (Onega-joen reitti) ja lännestä (Syvärin vesistöalue, KovžaVytegra, Tihvinka) tulevien vesiliikennereittien risteyksessä. Myöhäiskargopolin keramiikan piirteistä ja alueen merjalaistyyppisten hydronyymien määrästä päätellen ovat väestö- ja kulttuurivirtaukset nykyisten Jaroslavlin ja Kostroman alueilta (oblasteista) olleet pääasialliset faktorit kyseisen kulttuurin synnyssä. Saamelaisena pidettävä vesistönimistö on selvästi vähäisempää kuin vastaava ylävolgalainen ainakin Kargopolin ympäristössä.

\subsection{Ylävolgalainen nimistö}

Kuten jo moneen kertaan on edellä todettu, on ylävolgalainen nimistökerrostuma varsin vahva Kargopolin alueella. Kenozeron seudulla sitä ei taas ole nimeksikään. Rahkonen (2012: 20-27) on esittänyt, että huomioiden merjalaisalueilla nimikannoissa esiintyvät sanat veksa viksa 'kahden suuremman veden välinen lyhyehkö välijoki', uht- 'vetotaival, kannas', jäqrä 'järvi', molo 'joki, josta siirryttiin vesistöstä toiseen', il(e) 'ylä-', vol(o) 'ala-', nere-/mere- 'merjalainen', väz(ä) 'vähä' ja topoformantit -hta/-gda, -bal/-bol 'kylä', on merjaa puhuttu Valkeajärveltä itään aina Keski- Suhonalle asti. Lisäksi sen lähisukukieltä on puhuttu Äänisen ympäristössä ja Syvärillä. Manjuhinin (2005: 25) mukaan ylävolgalaisen tekstiilikeramiikan vaikutus myöhäiskargopolin kulttuurin keramiikassa on voimakkainta juuri Kargopolin alueella. Kenozeroa lähellä olevan Puudoisen-Vodlan alueella vanhan paikallisen tekstiilikeramiikan vaikutus on suurin ja Valkeajärvellä voimakkainta on AhmylovanAnan'inon keraamisen kulttuurin vaikutus.

19. Itä- ja länsitšuudien välinen raja kulki karkeasti ottaen Msta-joessa (Rahkonen 2013b: 243, map 2). 


\subsection{Muinaiset "paikalliset" kielet}

Nähdäkseni jotain paikallista luultavimmin länsiuralilaista kieltä on puhuttu "järvien välisellä alueella" ja Suhonalla sekä myös Kargopolin alueella. Tähän $x$-kieleen liittyvien hydronyymien nimikantoja ovat mm. $\operatorname{Kem}(V)-, \operatorname{Sond}(V)-, \operatorname{Ind}(V)-, \operatorname{Oht}(V)-(\mathrm{ks}$. Rahkonen 2013a: 21-27). Lisäksi Valkeajärven eteläpuolella on keskittymä hydronyymejä, joissa esiintyy jälkikomponentti -buj tai - $b o j<\beta o j<*$ woja 'oja, puro, joki' (kartta 4). Mm. Matveev (2001: 256-261) on katsonut sen liittyvän ns. parasaameen. Saarikivi (2004: 200, kartta 7) vuorostaan on suhtautunut tähän epäilevästi nostaen aiheellisestikin esiin mm. kyseisen tulkinnan äänteelliset ongelmat. Joka tapauksessa tähän liittyviä nimikantoja Am-, An-, Ar-, Čuž-, Hel-, Kače-, Kiz-, Laj-, Než-, Rot-, Sjam-, Uz-, Voro-, Šer- ja $\check{S} u \check{s}$ - on vaikea yhdistää saameen tai merjaan. Muutamat voisivat olla etnonyymejä kuten sjam säm(ä) 'saame' < *šämä, ar 'udmurtti, permiläinen', čuž < *čǔ̌ 'tšuudi'. Osalla saattaa olla vastineita komilaisessa nimistössä; vrt. An|ju < ay 'joen penger', Neč $\mid j u<n e z ̌-<n i t \breve{s} a$ 'sammalinen', Šer|ju < šęr 'keskijoki' (ks. Afanas'ev 1996), Uź < uź ? < voź 'niitty', Vora|šor ? < ver 'metsä' ja toisilla udmurttilaisessa nimistössä taas Kačo ? < *ka丂̌ 'verkko', Kiź|va $<k i z-?<$ kizíl|ni 'kylvää', $U z \mid j u k<u z-?<v o z ́$ 'niitty' (AUR). Nämä kaikki jäävät kuitenkin enemmänkin vain spekulatiivisiksi arvailuiksi. Tosin esim. Vože-järveen laskee joki nimeltä Čepca, mikä saattaa olla permiläinen siirtymänimi Udmurtian Čepcan alueelta. Lisäksi on otettava huomioon, kuten jo edellä on mainittu, että alkuaan alakamalainen Ahmylovan-Anan'inon keraaminen kulttuuri vaikutti voimakkaimmin myöhäiskargopolin kulttuuriin juuri Valkeajärven alueella (Manjuhin 2005: 25). Ainakin nimikantojen yksitavuisuus on tyypillistä permiläiskielille (ks. Rahkonen 2014: 335), mitä ei tässä tapauksessa voine kuitenkaan pitää kovin vahvana todisteena. Joissain, kuten Sodjärven kylän vepsän kielessä myös esiintyy $*_{\mathrm{v}}>b$ (Zajceva - Mullonen 1972: 624); ks. myös veps, beps (SSA 3 s. v. vepsä) vs. Valkeajärven eteläpuolen *woja $>*$ * ßoj, mikä saattaa olla samanlähtöistä vaikutusta. Lisäksi on täysin opaakkeja nimiä, joita on vaikea sijoittaa mihinkään ryhmään. Nämä saattavat olla peräisin jostain paleo-eurooppalaisesta kielestä.

\subsection{Loppusanat}

Valitettavasti edellä esitetty poikkitieteellinen tutkimus ei tällaisen artikkelin puitteissa voi olla kovin syvällistä. Kuitenkin toivon tämän työn johtavan pidemmälle menevään tutkimukseen ja olevan jonkinlainen avaus lingvisteille (niin fennougristeille kuin slavisteillekin), onomastikoille, arkeologeille sekä kansatieteilijöille. Lisämateriaalin löytäminen alkaa jo olla vaikeaa, joten asialla on kiire. Kylät autioituvat, vanhat ihmiset, jotka jotain vielä tietävät, poistuvat keskuudestamme, murteet yleiskielistyvät, vanhat tavat unohtuvat. Suomalais-ugrilainen menneisyys Kargopolin ja Kenozeron alueella, niin kuin monilla muillakin Venäjän Pohjolan seuduilla, lähettää ilta-auringon viimeisiä säteitään. Venäläiset historiankirjat yleensä alkavat ylimalkaisella lyhyellä maininnalla muinaisista suomensukuisista asukkaista ennen slaavien saapumista. Itse esitys kuitenkin säännönmukaisesti koskee aikoja, 
jotka kertovat slaavien migraatiosta. Lisäksi assimilaation ajoitus on pääsääntöisesti liian varhainen. Edes pakanuudenaikaista slaavilaista kulttuuria ei mielestäni ole tutkittu vielä kunnolla näillä alueilla. Varmaa on, ettei kristillisyys voinut vielä 900 $1200 \mathrm{jKr}$. olla slaavienkaan keskuudessa kovin syvälle juurtunutta.

\section{Lyhenteet}

\begin{tabular}{|c|c|c|c|}
\hline balt & balttilaiset kielet & $\mathrm{saP}$ & pohjoissaame \\
\hline ims & itämerensuomi & $\operatorname{sgr}$ & suomalais-ugrilainen \\
\hline $\mathrm{ka}$ & karjala & & kantakieli \\
\hline $\mathrm{kaE}$ & eteläkarjala & skand & skandinaaviset kielet \\
\hline $\mathrm{kaP}$ & pohjoiskarjala & $\mathrm{sm}$ & suomi \\
\hline kgerm & kantagermaani & smI & suomen itämurteet \\
\hline kperm & kantapermi & smInk & Inkerin suomalaismurteet \\
\hline $\mathrm{ksa}$ & kantasaame & sm.perm. & suomalais-permiläinen \\
\hline liet & liettua & & kantakieli \\
\hline ly & lyydi & ve & vepsä \\
\hline md & mordva & veE & etelävepsä \\
\hline $\mathrm{mdE}$ & ersämordva & veK & keskivepsä \\
\hline $\mathrm{ru}$ & ruotsi & ven & venäjä \\
\hline
\end{tabular}

\section{Lähteet}

\section{Kartat}

AJO = Атлас Ярославской области. 1:100 000. Москва: Роскартография. 2002.

$\mathrm{AKO}=$ Атлас Костромской области. 1:100 000. Тверь: Роскартография. 2009.

ALO = Атлас Ленинградская область, Санкт-Петербург. 1 : 200 000. Санкт-Петербург: ФГУП «Аэрогеодезия». 2005.

$\mathrm{AUR}=$ Атлас Удмуртская Республика. ФГУП Уралаэрогеодезия. 1:200 000. Екатеринбург. 2007

AVO = Атлас Вологодская область. 1:200 000. Санкт-Петербург: ФГУП «Аэрогеодезия». 2008.

GUGK/Arhangel' = Архангель-Главное управление геодезии и картографии. 1:100 000. Ленинград: ГУГК СССР. 1990.

GUGK/Kotlas = Котлас - Главное управление геодезии и картографии. 1:100 000. Ленинград: ГУГК СССР. 1990.

GUGK/Onega $=$ Онега - Главное управление геодезии и картографии. 1:500 000. Ленинград: ГУГК СССР. 1990.

TKRK = Топографическая карта: Республика Карелия. 1:200 000. Санкт-Петербург: ВТУ ГШ. 1997. 


\section{Kirjallisuus}

Afanas'ev = Афанасьев, А. П. 1996: Топонимия республики Коми. Сыктывкар. <http:// komikyv.com/archives/3801>.

Ahlqvist, Arja 1998: Kižila ja Kinela. - Riho Grünthal \& Johanna Laakso (toim.), Oekeeta asijoo. Commentationes Fenno-Ugricae in honorem Seppo Suhonen sexagenarii 16.5.1998. Suomalais-Ugrilaisen Seuran Toimituksia 228. Helsinki: SuomalaisUgrilainen Seura. 12-32.

Ahlqvist = Альквист, Арья 2000: Меряне не меряне...-Bопросы языкознания 2000: 2: $34-45$.

Ahlqvist, Arja 2001: Субстратная топонимия Ярославского Поволжя. - А. С. Герд \& Г. С. Лебедевб (toim.), Очерки исторической географии. Северо-Запад России. Славяне и финны. Санкт-Петербург: Издательство Санкт-Петербургского университа. 436-467.

Ahlqvist, Arja 2006: Ancient lakes in the former Finno-Ugrian territories of Central Russia: An experimental onomastic-palaeogeographical study. - Juhani Nuorluoto (toim.), The Slavicization of the Russian North. Mechanism and chronology. Slavica Helsingiensia 27. Helsinki: Department of Slavonic and Baltic Languages and Literatures. Helsinki University Press. 11-49.

Aikio, Ante 2006: On Germanic-Saami Contacts and Saami Prehistory. - Suomalais-Ugrilaisen Seuran Aikakauskirja 91: 42.

Bubrih = Бубрих, Д. В. 1997: Происхождение карельского народа. Петрозаводск.

Carpelan, Christian 1999: Käännekohtia Suomen esihistoriassa aikavälillä 5100..1000 eKr. - Paul Fågelberg (toim.), Pohjan poluilla. Suomalaisten juuret nykytutkimuksen mukaan. Bidrag till kännedom av Finlands natur och folk 153. Societas Scientiarum Fennica. 249-280.

Čistov = Чистов, К. В. 1958: Былина «Рахта Рагнозерский» и предание о Рахкое из Рагнозера. - Славянская филологя Вып. 3. Москва. 358-388.

Dal' = Даль, Владимир 1989 [1880-82]: Толковый словарь живого великорусского языка 1-4. [Näköispainos.] Москва: Издательство «Русский язык».

Derjagin , Derjagina \& Manihin = Дерягин В. Я., Дерягина 3. С. \& Манихин Г. И. 1987: Топонимика Кенозера 1-2. Архангельск: Архангельский ордена «Знак Почета» государственный педагогический институт им. М. В. Ломоносова.

ESRJ = Фасмер, Макс 2003: Этимологический словарь русского языка 1-3. Москва: Астрел. Аст.

Fedorov = Федоров, Б. Н. 1978: Каргополь и его окрестности. Ленинград: «Художник РСФСР».

GBO = Смолицкая Г. П. 1976: Гидронимия бассейна Оки. Москва.

Golubeva = Голубева, Л. А. 1973: Весь и славяне на Белом озере. Москва.

Gordeev = Гордеев, Ф.И. 1990: О контактах позднесарматских племен с волжкопермскими этническими группами. - Bопросы марийской ономастики. Вып. 7. Йошкар-Ола. 81-106.

Gunn = Гунн, Г. П. 1984: Каргопольский озерный край. Москва: «Искуство».

Haruzin = Харузин, Н. Н. 1894: Из материалов, собранных среди крестьян Пудожского уезда Олонецкой губернии. - Олонеикий сборник Вып. 3. Петрозаводск. 302-346.

Helimski, Eugen 2006: The northwestern group of Finno-Ugric languages and its heritage in the placenames and substratum vocabulary of the Russian North. - The Slavicization of the Russian North. Mechanism and chronology. Slavica Helsingiensia 27. Helsinki: Department of Slavonic and Baltic Languages and Literatures. Helsinki University Press. 109-127. 
Huurre, Matti 2001: 9000 vuotta Suomen esihistoriaa. Helsinki: Otava.

Häyhä, Johannes 1898: Kuvaelmia itä-suomalaisten vanhoista tavoista. Kesäaskareet. Helsinki: Suomalaisen Kirjallisuuden Seuran osakeyhtiö.

Itkonen, Terho 1981: Zur Geschichte der $t s$-Verbindung in den westfinnischen Dialekten. Heikki Leskinen (toim.), Heutige Wege der finnischen Dialektologie. Studia Fennica 24. Helsinki: Suomalaisen Kirjallisuuden Seura. 11-28.

Itkonen, Terho 1983: Välikatsaus suomen kielen juuriin. - Virittäjä 87: 190-229, 349-386.

Kalima, Jalo 1915: Die ostseefinnischen Lehnwörter im russischen. Helsingfors.

Kansalaisen karttapaikka: <http://kansalaisen.karttapaikka.fi/kartanhaku/osoitehaku. html?lang $=>$.

KKS = Torikka, Marja (verkkolaitoksen päätoim.) 2009, Karjalan kielen verkkosanakirja . Kotimaisten kielten tutkimuskeskuksen verkko-julkaisuja 18. $-<$ http://kaino.kotus.fi/ cgi-bin/kks/kks_etusivu.cgi>.

Koivulehto, Jorma 1987: Namn som kan tolkas urgermansk. - Studier i nordisk filologi 67: $27-42$.

Komjagina = Комягина, Л. П. 1994: Лексический Атлас Архангельской области. Архангельск: Издательство поморского международного педагогического университа им. М. В. Ломоносова.

Kuzmin, Denis 2013: Saamelainen asutus Karjalassa. - Suomalais-Ugrilaisen Seuran Aikakauskirja 94: 129-183.

Lehtiranta, Juhani 2001: Yhteissaamelainen sanasto. Suomalais-Ugrilaisen Seuran Toimituksia 200. Helsinki: Suomalais-Ugrilainen Seura.

Leont'ev, A.E. 1996: The archaeology of the Merya. (The early history of North-Eastern Russia). - Gennadii E. Afanas'ev, Falko Daim in collaboration with Dafydd Kidd (toim.), Russian Monographs in Migration Period and Medieval Archaeology Volume 4. Moscow: Russian Academy of Sciences, Institute of Archaeology. 316-338.

Loginov = Логинов, К. К. 1999: Ещё раз о «вепсском» прошлом водлозерья. - И. И. Винокурова (toim.) Bencы: История, культура и межэтнические контакты. Сборник научных трудов. Петрозаводск: Карельский научный центр РАН, институт языка, литературы и истории. Издательство петрозаводского государственного унивеситета. 104-111.

MAG = Муллонен И. И., Азарова И. В. \& Герд А. С. 1997: Словарь гидронимов юговосточного Приладожья, басейн реки Свирь. Санкт-Петербург: Издательство Санкт- Петербургского университа.

Makarov, N. A. 2006: Cultural identity of the Russian North settlers in the 10th - 13th centuries. - Juhani Nuorluoto (toim.), The Slavicization of the Russian North. Mechanism and chronology. Slavica Helsingiensia 27. Helsinki: Department of Slavonic and Baltic Languages and Literatures \& Helsinki University Press. 259-281.

Makarova = Макарова, Анна 2012: Русская озерная гидронимия Белозерья: СистемноФункииональный аспект. Диссертация на соискание ученой степени кандидата филологических наук. Екатеринбург: Уральский федеральный университет.

Manjuhin = Манюхин, Игорь 1996: Позднекаргопольская культура. Саамы (культовые памятники). - М.Г. Косменко, С. Кочкуркина (toim.), Археология Карелии. Петрозаводск. 220-238.

- 2005: Этногенез Саамов (опыт комплексного исследования). Ижевск: Автореферат диссертации на соискание ученой степени доктора исторических наук. - Autoreferaatti <http://elibrary.udsu.ru/xmlui/handle/123456789/655>.

Matveev = Матвеев, А. К. 2001: Субстратная топонимия Русского Севера. Ч. 1. Екатеринбург: Издательство Уральского унивесита. 
Matveev, А. 2004 = Субстратная топонимия Русского Севера. Ч. 2. Екатеринбург: Издательство Уральского унивесита.

Mullonen = Муллонен, И. И. 1995: Заметки о топоними Водлозерья. - Природное $u$ культурное наследие Водлозерского наиионального парка. Петрозаводск. 192-197.

Mullonen, Irma $2002=$ Топонимия Присвирья. Проблемь этноязыкого контактирования. Петрозаводск: Российская академия наук. Карельский научный центр: институт языка, литературы и истории.

Mullonen, Irma 2003 = Прибалтийско-финские народы России. Москва.

Mullonen, Irma 2005 = Vepsän etnisen alueen muodostuminen paikannimistön perusteella. - Lassi Saressalo (toim.), Vepsä. Maa, kansa ja kulttuuri. Tampereen museoiden julkaisuja 81 \& Suomalaisen Kirjallisuuden Seuran Toimituksia 1005. Tampere. 48-63.

Mullonen, Irma $2008=$ Топонимия Заонежья. Словарь с историко-культурными комментариями. Топонимия Присвирья. Проблемы этноязыкого контактирования. Петрозаводск.

Mullonen \& Zaharova = Муллонен, И.И. \& Захарова, Е.В. 2013: Многослойная топонимия Кенозерья. - Кенозерские Чтения - 2011. Человек и среда: Гармония и противоречия. Сборник материалов V Всероссийской научно-практической конференции. Архангельск. 152-162.

$\mathrm{MWB}=H$. Paasonen's Mordwinisches Wörterbuch 1-4. Lexica Societatis Fenno-Ugricae XXIII. Helsinki: Suomalais-Ugrilainen Seura. 1990-1996.

Myznikov = Мызников, Сергей 2003a: Атлас субстратной и заимствованной лексики русских говоров Северо-Запада. Санкт-Петербург: Наука.

Myznikov, Sergei 2003b = Русские говоры Обонежья. Ареально-зтимилогическое исследование лексики прибалтийско-финского происхождения. СанктПетербург: Наука.

$\mathrm{NA}=$ Kotimaisten kielten keskuksen nimiarkisto.

Nuorluoto, Juhani 2006: Is there a sound change of "e $>o$ " in Russian? - Juhani Nuorluoto (toim.), The Slavicization of the Russian North. Mechanism and chronology. Slavica Helsingiensia 27. Helsinki: Department of Slavonic and Baltic Languages and Literatures \& Helsinki University Press. 293-308.

Patrushev, Valery 2000: The early history of the Finno-Ugric peoples of European Russia. Oulu: Societas Historiae Fenno-Ugricae.

Pimenov = Пименов, В. В. 1965: Bencbl. Москва-Ленинград.

Popov $=$ Попов, А. И. 1973: Лача. - Русская речь 4: 129-130.

Požarickaja = Пожарицкая, Софья 1997: Русская диалектология. Москва: Издательство Московского университа.

Proničeva = Проничева, Нина 1996: Журавлиный край (природа Каргополья). Архангельск.

Rahkonen, Pauli 2011: Finno-Ugric hydronyms of the river Volkhov and Luga catchment areas. - Suomalais-Ugrilaisen Seuran Aikakauskirja 93: 205-266.

Rahkonen, Pauli 2012: Границый распространия меряно-муромских и древнемордовских гидронимов в верховьях Волги и бассейне реки Оки. Вопросы Ономастики 2012: 1: 5-42.

Rahkonen, Pauli 2013a: Suomen etymologisesti hämärää vesistönimistöä. - Virittäjä 117: $5-43$.

Rahkonen, Pauli 2013b: Conclusions. - South eastern contact area of Finnic languages in the light of onomastics. Jyväskylä: Bookwell. 235-246.

Rahkonen, Pauli 2014: The Western Spread of Permic Hydronyms. - Finnisch-Ugrische Forschungen 62: 327-375. 
Rjabinin = Рябинин, Е.А. 1997: Финно-Угорские племена в составе древней Руси. Санкт-Петербург: Санкт-Петербургский государственный университет. Институт истории материалной культуры РАН \& Издатеьство Санкт-Петербургского университа.

Saarikivi, Janne 2004: Über die saamischen Substratennamen des Nordrusslands und Finnlands. - Finnisch-Ugrische Forschungen 58: 162-234.

Saarikivi, Janne 2006a: Introduction. - Substrata Uralica. Tartu: Tartu University Press.

Saarikivi, Janne 2006b: Article 2: On the Uralic substrate toponymy of Arkhangelsk region: problems of research methodology and ethnohistorical interpretation. - Substrata Uralica. Tartu: Tartu University Press.

Sammallahti, Pekka 1988: Historical phonology of Uralic languages. With special reference to Samoyed, Ugric and Permic. - Denis Sinor (toim.), Uralic languages. Leiden: E. J. Brill. 478-554.

Sammallahti, Pekka 1989: Sámi-Suoma Sátnegirji. Ohcejohka: Jorgaleaddji Oy.

Sammallahti, Pekka \& Morottaja, Matti 1993: Säämi-suomâ sänikirje. Ohcejohka: Girjegiisá.

SPK = Sirkka Paikkala (päätoim.) 2007, Suomalainen paikannimikirja. Kotimaisten kielten tutkimuskeskuksen julkaisuja 146. Helsinki: Karttakeskus \& Kotimaisten kielten tutkimuskeskus. 2007.

$\mathrm{SMJ}=$ Словарь марийского языка 1-10. Päätoimittaja С. Галкин. Йошкар Ола: Научно шымлыше марий институт. 1990-2005.

$\mathrm{SMS}_{8}=$ Vilppula, Matti \& Takala, Ulla (toim.) 2008: Suomen murteiden sanakirja 8. Helsinki: Suomalainen Kirjallisuuden Seura \& Kotimaisten kielten tutkimuskeskus.

$\mathrm{SSA}=$ Suomen sanojen alkuperä 1-3. Etymologinen sanakirja. Helsinki: Suomalaisen Kirjallisuuden Seura \& Kotimaisten kielten tutkimuskeskus. 1992-2000.

Tkačenko = Ткаченко, О. Б. 2007: Исследования по мерянскому языку. Кострома.

Višnevskaja \& Gorohov = Вишневская, Светлана \& Горохов, Владислав 1997: Национальные парки России. Москва: Библиосфера.

Zajceva \& Mullonen = Зайцева, М. И. \& Муллонен, М. И. 1972: Словарь вепского языка. Ленинград: Академия наук СССР, Карельский филиал. Институт языка, литературы и истории \& Издательство «Наука», Ленинградское отделение. 